PNNL-11036

RECEIVED Project Technical Information MAR 281996

OSTI

OWL Models Update and Use for

TWRS Strategy Development

M. Hoza

March 1996

Prepared for the U.S. Department of Energy under Contract DE-AC06-76RLO 1830

Pacific Northwest National Laboratory Operated for the U.S. Department of Energy by Battelle Memorial Institute 
PNNL-11036

UC-810

Project Technical Information

\title{
OWL Models Update and Use for TWRS Strategy Development
}

\author{
M. Hoza
}

March 1996

Prepared for

the U.S. Department of Energy

under Contract DE-AC06-76RLO 1830

Pacific Northwest National Laboratory

Richland, Washington 99352

Reprint of historical document PVTD-C95-02.04A, dated September 1995. Data, formatting, and other conventions reflect standards at the original date of printing. Technical peer reviews and editorial reviews may not have been performed. 


\title{
DISCLAIMER
}

This report was prepared as an account of work sponsored by an agency of the United States Covernment. Neither the United States Government nor any agency thereof, nor Eattelle Memorial Institute, nor any of their employees, makes any warranty, express or implied, or assumes any legal liability or sesponsibility for the accuracy, completeness, or usefulness of any information, apparatus, product, or process disclosed, or represents that its use would not infringe privately owned rights. Reference herein to any specinic commercial product, process, or service by trade name, trademark, manufacturer, or othenvise does not necessarily constitute or imply its endorsement, recommendation, or favoring by the United States Government or any agency thereof, or Earielle Memorial Instiute. The views and opinions of authors expressed herein do not necessarily state or reflect those of the United States Government or any agency thereof.

\author{
PACIFIC NORTHWEST NATIONAL LABORATORY \\ operated by \\ BATTELLE \\ for the \\ UNITED STATES DEPARTMENT OF ENERGY \\ under Contract DE-AC06-76RLO 1830
}

Printed in the United States of America

Available fo DOE and DOE contractors from the

Ofirce of Scientific and Technical information, P.O. BOx 62, Oak Ridge, TN 37837; prices, available from (615) 576-8401.

Available to the public from the National Technical Information Service, U.S. Department of Commerce, 5285 Port Royal Rd., Springfield, VA 22161 


\section{Summary}

This report presents the results of the development work on the Optimal Waste Loading (OWL) models for FY95. Work was focused in four areas, each of which is discussed below.

The OWL glass property models were updated to be consistent with the latest models based on the experimental glass formulation and modeling work. The updated models include property model uncertainty, permitting the optimization to account for this uncertainty in the calculation.

The OWL model architecture was revised to be more modular. The new architecture enables all OWL models to use the same core model files, facilitates integrating OWL with other Hanford models, and enables the use of the Ternary Waste Envelope Assessment Tool (TWEAT) to view the results of all OWL model calculations. The Base, Uncertainty, and Discrete Blend Models have been converted to the new architecture.

The interface to TWEAT was enhanced. The enhancements make it possible to use TWEAT to view the results of any OWL model calculation and to access both OWL and TWEAT from any IBM-compatible or Macintosh-compatible personal computer, or any engineering workstation on the Pacific Northwest Laboratory (PNL) network.

Several simple high-level strategies for blending all Hanford high-level waste were evaluated for a set of tank farm composition data (Lambert and Kim, 1994). Results suggest that, if it is possible to blend all high-level waste to form four blends, the required volume of high-level waste glass will be the same as if all wastes were blended together. An overall processing and blending strategy that should make it possible to achieve the processing and blending to four blends is described. The benefits of such a strategy are:

- Less glass would be required, potentially resulting in a savings of billions of dollars (relative to not blending at all).

- Fewer distinct high-level wastes would result. This would greatly simplify experimental glass and feed rheology work.

- The strategy could provide a reference technical basis for engineering decisions.

The strategy must be rigorously evaluated against other strategies from a system life-cycle cost perspective. An approach for implementing and evaluating the strategy is proposed. 


\section{Acknowledgments}

The author gratefully acknowledges the contributions of the following:

- Don Larson for his guidance and programmatic support for the development of the OWL models.

- Ross Lambert and Bob Robertus for their efforts in interfacing OWL and TWEAT.

- Trish Redgate for providing the new property and uncertainty model coefficients and explaining how to implement the Fulcher and Arrhenius uncertainty models. 


\section{Contents}

Summary $\ldots \ldots \ldots \ldots \ldots \ldots \ldots \ldots \ldots \ldots \ldots \ldots \ldots \ldots \ldots$ iii

Acknowledgments $\ldots \ldots \ldots \ldots \ldots \ldots \ldots \ldots \ldots \ldots \ldots \ldots \ldots$ iv

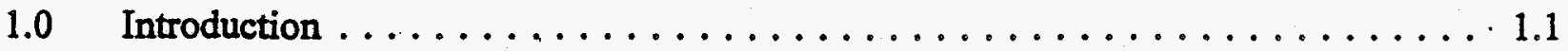

2.0 Incorporation of Updated Glass Property and Property Uncertainty Models . . . . 2.1

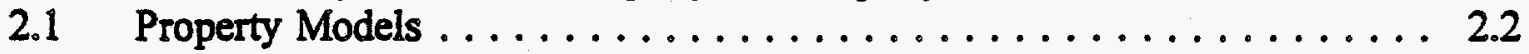

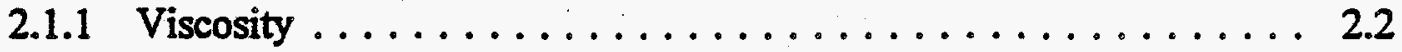

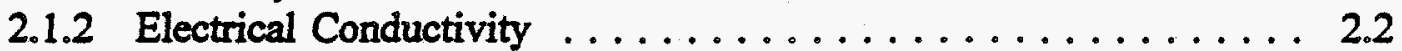

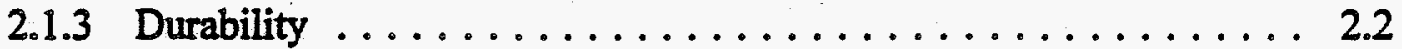

2.1.4 Liquidus Temperatures $\ldots \ldots \ldots \ldots \ldots \ldots \ldots \ldots \ldots . \ldots \ldots$

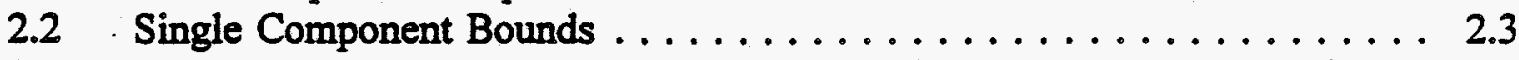

2.4 Property Uncertainty Models $\ldots \ldots \ldots \ldots \ldots \ldots \ldots \ldots \ldots \ldots \ldots \ldots$

3.0 Updating OWL Model Architecture $\ldots \ldots \ldots \ldots \ldots \ldots \ldots \ldots \ldots \ldots . \ldots \ldots$

4.0 OWL Interface with TWEAT $\ldots \ldots \ldots \ldots \ldots \ldots \ldots \ldots \ldots \ldots \ldots \ldots \ldots \ldots$

5.0 Overall Tank Blending Scenario Analyses . . . . . . . . . . . . 5.1

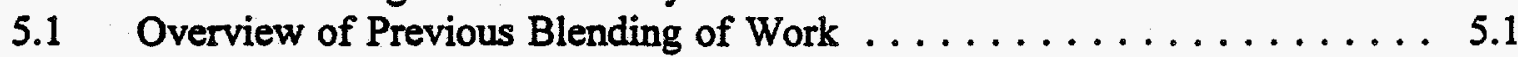

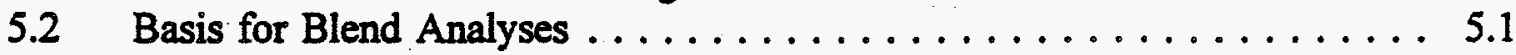

$5.3 \quad$ Blending Scenario Results $\ldots \ldots \ldots \ldots \ldots \ldots \ldots \ldots \ldots \ldots .2$

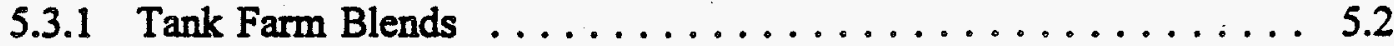

5.3.2 Cr-Metered Blends ..................... 5.3

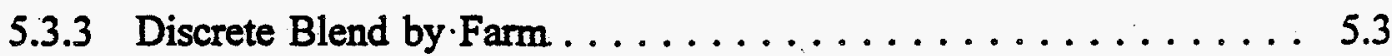

5.3.4 Discrete Blend by "Tank" . . . . . . . . . . . . . . 5.3

5.3 .5 Total Blend . . . . . . . . . . . . . . . . . 5.4

6.0 Proposed Retrieval, Processing, and Blending Strategy . . . . . . . . . 6.1

$6.1 \quad$ Motivation for Processing Strategy $\ldots \ldots \ldots \ldots \ldots \ldots \ldots \ldots \ldots .1$

6.2 Description of Processing Strategy $\ldots \ldots \ldots \ldots \ldots \ldots \ldots \ldots .3$

6.3 Description of Implementation and Evaluation Strategy $\ldots \ldots \ldots \ldots 6.5$

7.0 Conclusions and Recommendations $\ldots \ldots \ldots \ldots \ldots \ldots \ldots \ldots \ldots \ldots$

$8.0 \quad$ References $\ldots \ldots \ldots \ldots \ldots \ldots \ldots \ldots \ldots \ldots \ldots \ldots \ldots \ldots \ldots \ldots \ldots$ 
Appendix A - Glass Property Model Coefficients .................. A.1

Appendix B - Covariance Matrices for OWL Uncertainty Model ............ B.1

Appendix C - Blending Behavior Summary from FY94 Blend Report $\ldots \ldots \ldots \ldots$ C.1

Appendix D - Waste Compositions - Tank Farm Blends ............. D.1 


\section{Figures}

6.1 HL Waste Composition Space Comparison - Current vs

Two Optimal Blending Strategies $\ldots \ldots \ldots \ldots \ldots \ldots \ldots \ldots . \ldots .2$

6.2 Schematic Representative of Proposed TWRS Processing Strategy . . . . . . . 6.4

\section{Tables}

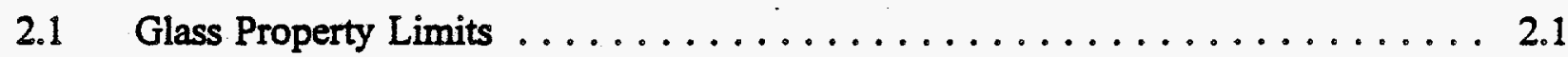

2.2 Upper and Lower Limits on the Mass Fractions of the Ten CVS Components . . . 2.4

2.3 Upper Limits on Mass Fractions of Solubility Components . . . . . . . . . . . 2.4

3.1 OWL Model Files for Revised Model Architecture . . . . . . . . . . . . 3.1

$5.1 \quad$ Blend Scenario Analysis Results . . . . . . . . . . . . . . . 5.2

5.2 Optimal Assignments for Discrete Blend by "Tank" . . . . . . . . . . . . 5.4

5.3 Calculated Results for Blend $1 \ldots \ldots \ldots \ldots \ldots \ldots \ldots \ldots \ldots$

5.4 Calculated Results for Blend $2 \ldots \ldots \ldots \ldots \ldots \ldots \ldots \ldots \ldots \ldots \ldots \ldots \ldots \ldots \ldots$

$5.5 \quad$ Calculated Results for Blend $3 \ldots \ldots \ldots \ldots \ldots \ldots \ldots \ldots \ldots \ldots$

$5.6 \quad$ Calculated Results for Blend $4 \ldots \ldots \ldots \ldots \ldots \ldots \ldots \ldots \ldots \ldots \ldots$ 


\subsection{Introduction}

High Level Waste (HLW) at Hanford will be converted to a borosilicate glass for disposal. The glass will need to meet both processability and durability restrictions. The processability conditions will ensure that the glass has properties (viscosity, electrical conductivity, and liquidus temperature) within ranges known to be acceptable for the vitrification process. Durability restrictions will ensure that the resultant glass will meet quantitative criteria for disposal in a repository.

An experimental program, the Composition Variation Study (CVS), is developing property models which correlate physical properties to glass compositions (Hrma, Piepel, et al. 1994). Property models have been developed for the viscosity, electrical conductivity and liquidus temperature of the glass melt, and durability of the glass. The property models are described in the above report. Bounds on property values, limits on the composition of individual components in the glass, and other restrictions are also published in the report.

The Optimal Waste Loading (OWL) models are being developed as a set of tools to aid the waste and glass evaluation and glass design processes. In the most basic implementation, the OWL model will calculate the maximum waste loading and an optimal frit composition such that all constraints on the glass (as identified in the CVS study) are satisfied. The earliest implementation of the OWL models (as described in the 1993 OWL report ${ }^{(\mathrm{a})}$ ) has been used to identify limiting constraints, evaluate blending strategies, evaluate the effectiveness of pretreatment processes, and to explore the effects of property model uncertainty and Hanford Waste Vitrification Plant (HWVP) recycle on waste loading.

Additional developments were described in the 1994 OWL report $\mathrm{t}^{\mathrm{b}}$. These included verifying and validating the base OWL model, developing and demonstrating an approach for

- Hoza, M. 1993. Optimal Waste Loading Models for Vitrification of Hanford HighLevel Waste. PHTD-C93.03.01M, Pacific Northwest Laboratory, Richland, Washington.

- Hopkins, D.F., M. Hoza and C.A. Lo Presti, 1994. FY94 Optimal Waste Loading Models Development. PVTD-C94.02.04D. Pacific Northwest Laboratory; Richland, Washington. 
handling waste composition uncertainty in the calculation, and developing a file interface to the Ternary Waste Envelope Assessment Tool (TWEAT) ${ }^{(\mathbf{a})}$

This report addresses the continuation of the development of the OWL models. The objectives of the work described in this report are listed below:

1. Update the Glass Property Models in OWL. Incorporate the glass property models and constraints from the most recent CVS report (Hrma, Piepel, et al. 1994). These include temperature dependent models for viscosity and electrical conductivity. This work is described in Section 2.

2. Convert OWL to the more flexible Process Chemistry Model architecture. This reduces the need to maintain multiple versions of the core model code to support the different versions of OWL, and will facilitate the use of OWL with related TWRS programs and with tank inventory data. This work is described in Section 3. .

3. Enhance the interface to TWEAT. The enhanced OWL-TWEAT interface now facilitates the use of TWEAT for visual examination of OWL results, and enables access to both programs from the PNL network. This work is described in Section 4.

4. Complete a preliminary technical study to determine optimal glass types/formulations, waste pretreatment/retrieval approach and melter systems to assist in establishing program direction. This study will provide bases for determining approaches for glass formulation and feed preparation strategies. This work is described in Sections 5 and 6.

- Robertus, R.J., and R. Lambert. 1995. TWEAT '95 User's Documentation Update. PVTD-C95-02.04B. Pacific Northwest Laboratory, Richland, Washington. 


\subsection{Incorporation of Updated Glass Property and Property Uncertainty Models}

Glass property models developed as part of the Composition Variation Study (CVS) are incorporated into OWL as constraints for the optimization calculation (see 1993 OWL report ${ }^{2}$ ). The FY94 CVS report (Hrma and Piepel et al., 1994) is the most recent report on the results of the study. This section discusses the incorporation of the glass property models, the property model uncertainties, and component bounds from the FY94 CVS report into OWL.

Table 2.1 Glass Property Limits

\begin{tabular}{||l||l|l|}
\hline Property, units & Minimum Property Value & Maximum Property Value \\
\hline \hline Viscosity, PaS & 2 & 10 \\
\hline Electrical Conductivity, S/m & 10 & 100 \\
\hline $\begin{array}{l}\text { Durability (Release rate of } \\
\text { boron by PCT), } \mathrm{g} / \mathrm{m}^{2}\end{array}$ & Not Applicable (N/A) & 8.2 \\
\hline $\begin{array}{l}\text { Durability (Release rate of } \\
\text { lithium by PCT), } \mathrm{g} / \mathrm{m}^{2}\end{array}$ & N/A & 4.8 \\
\hline $\begin{array}{l}\text { Durability (Release rate of } \\
\text { sodium by PCT), } / \mathrm{m}^{2}\end{array}$ & N/A & 6.6 \\
\hline $\begin{array}{l}\text { Liquidus Temperature, }{ }^{\circ} \mathrm{C} \\
\text { Clinopyroxene }\end{array}$ & N/A & 1050 \\
\hline $\begin{array}{l}\text { Liquidus Temperature, }{ }^{\circ} \mathrm{C} \\
\text { Spinel }\end{array}$ & N/A & 1050 \\
\hline $\begin{array}{l}\text { Liquidus Temperature, }{ }^{\circ} \mathrm{C} \\
\text { Zr-containing crystals }\end{array}$ & N/A & 1050 \\
\hline
\end{tabular}

a Hoza, M. 1993. Optimal Waste Loading Models for Vitrification of Hanford HighLevel Waste. PHTD-C93.03.01M, Pacific Northwest Laboratory, Richland, Washington. 


\subsection{Property Models}

The property models for viscosity and electrical conductivity of the melt and durability of the glass were updated in the OWL model; property models were added for liquidus temperature of the glass. Only a brief discussion on each of the models will be presented below. For more information on each of these models, refer to the FY94 CVS report. The default limits on the properties (which are consistent with the CVS Qualified Composition Region) are given in Table 2.1. The limits can easily be changed in the HL_Constraints.ip file before performing a calculation run. The OWL model file containing the property model coefficients is listed in Appendix A.

\subsubsection{Viscosity}

The nonlinear viscosity model in OWL was replaced by a Fulcher viscosity model. The predicted viscosity is calculated as shown in equation (1)

$$
\ln \eta=\sum_{i=1}^{10} A_{i}+\sum_{i=1}^{10} B_{i} /\left(T-\sum_{i=1}^{10} T_{i} x_{i}\right)
$$

where $A_{i}, B_{i}$, and $T_{i}$ are empirical Fulcher model coefficients, $x_{i}$ are the mass fractions of the ten components included in the glass property models, and $T$ is the melter temperature in degrees $\mathbf{C}$.

\subsubsection{Electrical Conductivity}

The nonlinear electrical conductivity model was replaced by an Arrhenius electrical conductivity model. The predicted electrical conductivity $\epsilon$ is calculated as shown in equation (2)

$$
\ln \epsilon=\sum_{i=1}^{10} A x_{i}+\sum_{i=1}^{10} B_{i} x / T
$$

where $A_{i}$ and $B_{i}$ are empirical Arrhenius model coefficients, $x_{i}$ are the mass fractions of the ten components included in the glass property models, and $\mathrm{T}$ is the melter temperature in Kelvin.

\subsubsection{Durability}

The calculation of Materials Characterization Center (MCC-1) test durability has been dropped; Product Consistency Test (PCT) durabilities for boron, lithium, and sodium are 
now calculated using the updated property model coefficients given in Appendix A. PCT durabilities (actually normalized elemental releases) are calculated using second order models, as shown in equation (3).

$$
\ln r=\sum_{i=1}^{10} A_{i} x_{i}+\sum_{i=1}^{10} \sum_{j=1} B_{i j} x_{i j}
$$

where $A_{i}$ and $B_{i j}$ are empirical first and second order model coefficients, respectively, and $x_{i}$ are the mass fractions of the ten components included in the glass property models.

\subsubsection{Liquidus Temperatures}

Linear liquidus temperature models for clinopyroxene, spinel, and $\mathrm{Zr}$-containing species have been added to OWL. The calculation for each is as shown in equation (4)

$$
T_{L}=\sum_{i=1}^{10} A_{i} x_{i}
$$

where $A_{i}$ are empirical first order model coefficients, and $x_{i}$ are the mass fractions of the ten components included in the glass property models.

\subsection{Single Component Bounds}

With the exception the upper bound on $\mathrm{Al}_{2} \mathrm{O}_{3}$ (which increased from 0.15 to 0.17 ), all single component bounds are unchanged from those used in OWL ' 94 . The default component bounds currently used in OWL are given in Tables 2.2 and 2.3. These bounds are consistent with the CVS Qualified Composition Region. Component bounds are specified in the file HL_Constraints.ip, and can be modified, if desired, for a particular calculation. 
Table 2.2 Upper and Lower Limits on the Mass Fractions of the Ten CVS Components

\begin{tabular}{|l|l|l|}
\hline \hline Lower Limit & Component & Upper Limit \\
\hline 0.42 & $\mathrm{SiO}_{2}$ & 0.57 \\
\hline 0.05 & $\mathrm{~B}_{2} \mathrm{O}_{3}$ & 0.20 \\
\hline 0.05 & $\mathrm{Na}_{2} \mathrm{O}$ & 0.20 \\
\hline 0.01 & $\mathrm{Li}_{2} \mathrm{O}$ & 0.07 \\
\hline 0 & $\mathrm{CaO}$ & 0.10 \\
\hline 0 & $\mathrm{MgO}_{2}$ & 0.08 \\
\hline 0.02 & $\mathrm{Fe}_{2}$ & 0.15 \\
\hline 0 & $\mathrm{Al}_{2} \mathrm{O}_{3}$ & 0.17 \\
\hline 0 & $\mathrm{ZrO}_{2}$ & 0.13 \\
\hline 0.01 & Other & 0.10 \\
\hline \hline
\end{tabular}

Table 2.3 Upper Limits on Mass Fractions of Solubility Components

\begin{tabular}{|l|l|}
\hline Solubility Component & Upper Limit \\
\hline $\mathrm{Cr}_{2} \mathrm{O}_{3}$ & 0.005 \\
\hline $\mathrm{F}$ & 0.017 \\
\hline $\mathrm{P}_{2} \mathrm{O}_{5}$ & 0.01 \\
\hline $\mathrm{SO}_{3}$ & 0.005 \\
\hline Noble Metals $\left(\mathrm{Rh}_{2} \mathrm{O}_{3}+\mathrm{PdO}+\mathrm{Ru}_{2} \mathrm{O}_{3}\right)$ & 0.025 \\
\hline
\end{tabular}

\subsection{Property Uncertainty Models}

The approach used to account for property model uncertainty in OWL calculations was described in the FY93 OWL report. In that approach the size of the feasible region is reduced by the uncertainties in the property models. The property value constraint (with uncertainty) can then be expressed as equation (5) 
where

MinVal = the minimum acceptable value of the property

MaxVal = the maximum acceptable value of the property.

For each property, the uncertainty in a constraint for a particular composition can be expressed as in equation (6)

$$
\text { Uncert }=M\left[x^{T} S x\right]^{0.5}
$$

where

$M=$ multiplier, which is usually the upper 95 th percentile of a $t$-distribution $[t .95(n-p)]$, where $n$ is the number of data points used to fit the model and $p$ is the number of fitted parameters (coefficients) in the model

$x=$ glass composition vector expanded in the form of the model

$\mathbf{x}^{\mathrm{T}}=$ transpose of glass composition vector expanded in the form of the model

$S$ = covariance matrix of the estimated parameters (coefficients).

To calculate Uncert for all but the linear (liquidus temperature) models, the glass composition vector must be expanded. For durability models, the composition vector is augmented by second-order terms. For example, if there are two second-order terms, $x_{1}^{2}$ and $x_{2} x_{4}$, the usual composition vector $\left(x_{1}, \ldots, x_{10}\right)$ becomes $\left(x_{1}, \ldots, x_{10}, x_{1}{ }^{2}, x_{2} x_{4}\right)$. For the Fulcher viscosity model and Arrhenius electrical conductivity model, the composition vector is more complex. For the Fulcher viscosity model, the composition vector becomes (equation (7))

$$
\left[x_{1}, \ldots, x_{10}, \frac{\partial \ln \eta}{\partial B_{1}}, \ldots, \frac{\partial \ln \eta}{\partial B_{10}}, \frac{\partial \ln \eta}{\partial T_{1}}, \ldots, \frac{\partial \ln \eta}{\partial T_{10}}\right]
$$

while the Arrhenius composition vector becomes (equation (8)) 


$$
\left[x_{1}, \ldots, x_{10}, \frac{\partial \ln \epsilon}{\partial B_{1}}, \ldots, \frac{\partial \ln \epsilon}{\partial B_{10}}\right]
$$

The covariance matrices for all property models are given in Appendix B. 


\subsection{Updating OWL Model Architecture}

The previous OWL architecture (see FY93 OWL report) used common input files for the various OWL models (Base, Base with property model uncertainty, Base with Recycle, Discrete Blend Model), but different core model files. This made it necessary to maintain multiple copies of the same information, and did not support combinations of the models (say blend model with uncertainty). In the new model architecture, based on the Process Chemistry Model architecture (see Appendix A in FY94 OWL report), all models work from the same core files and combinations of the models are supported. A model is built at run time by assembling the appropriate model segments into a single model file. The set of files needed for each of the models is given in Table 3.1. For a given model, files that are specific to that model appear only in that model's column. Files that are used by multiple models are shown in rows that span multiple columns.

Conversion to the new architecture facilitated the updating of the glass property models and enables the use of TWEAT to view the results of any OWL model calculation. The new architecture will also facilitate the development of data filters ( $<$ HL_OWL-HLV.flt $>$ in the table above) for interfacing OWL with other Hanford models and the ability to use tank inventory data (rather than pretreated high-level waste compositions) for a calculation.

The Base, Model Uncertainty, and Discrete Blend versions are implemented; the Recycle model has not yet been converted to the new architecture.

Table 3.1. OWL Model Files for Revised Model Architecture

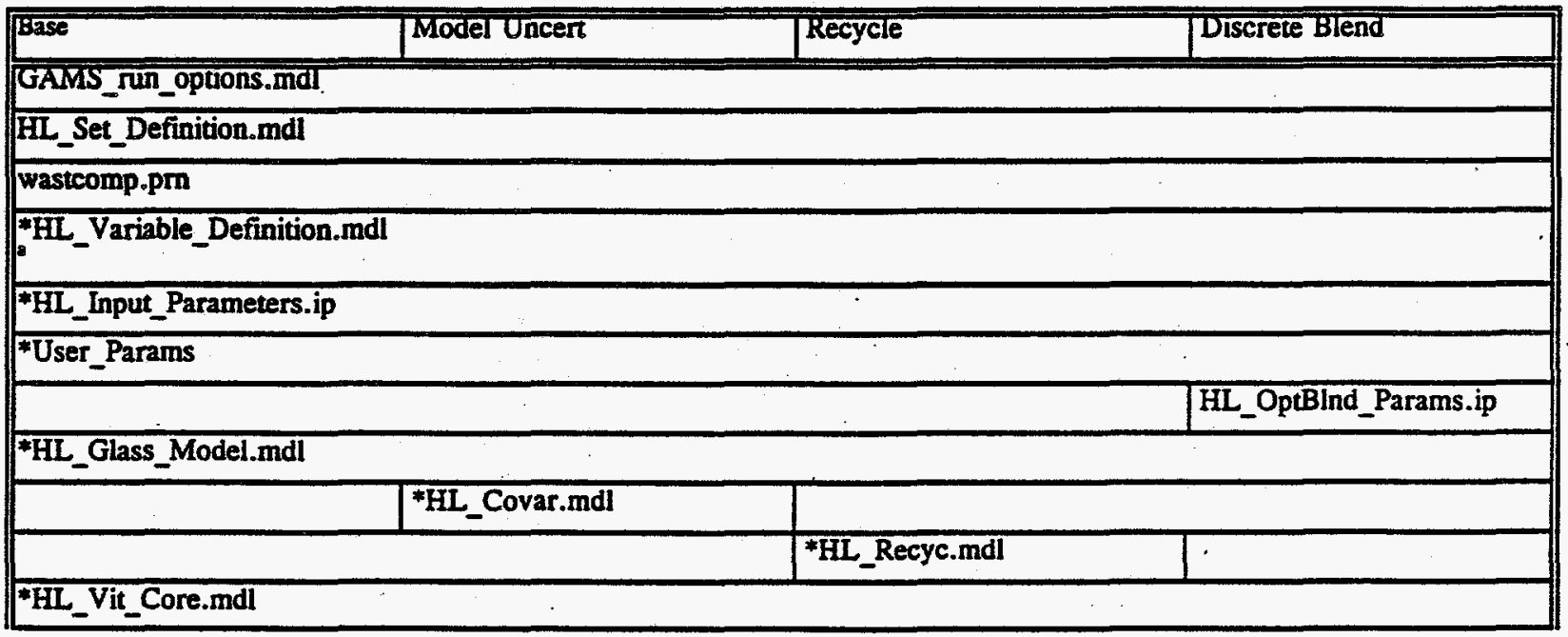

a Files marked with an asterisk are also used for overall (Process Chemistry) models 


\begin{tabular}{|c|c|c|c|}
\hline HIL_Vit_Base_Adj.mdl & 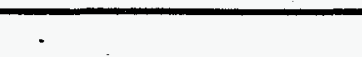 & & \\
\hline & HL_Vit_Uncert_Adj.mdl & & \\
\hline & & "HL_Vit_Recycle_Adj.mdl & \\
\hline & & & "HL_Vit_OptBInd_Adj.mdl \\
\hline \multicolumn{4}{|l|}{$<$ KIL_Mdl_Decl.mdl's $\rangle^{b}$} \\
\hline \multicolumn{4}{|l|}{ HL_Constraints.ip } \\
\hline \multicolumn{4}{|c|}{$\begin{array}{l}\text { "HL_Frit_Component_Bound } \\
\text { s.ip }\end{array}$} \\
\hline \multicolumn{3}{|c|}{${ }^{H} \mathrm{HL}$ _nitial_Values.ipe } & ${ }^{* H L}$ _Init_Val_OptBInd.ip \\
\hline \multicolumn{4}{|l|}{$*<\mathrm{HL}_{\text {_OWL-HLV.flt }>}$} \\
\hline \multicolumn{3}{|l|}{ <HL_CaleSpec.mdi > } & HI__CalcOptBl.mdl \\
\hline \multicolumn{4}{|l|}{ HL_Waste_Input_report.mdl } \\
\hline \multicolumn{3}{|l|}{ *HL_Solve_NLP .mdl } & *HL_Solve_MINLP.mdl \\
\hline \multicolumn{4}{|l|}{ HL_Postprocessor .mdl } \\
\hline \multicolumn{3}{|l|}{$\begin{array}{l}\text { LoopEnd.mdl for loop } \\
\text { calculations }\end{array}$} & \\
\hline
\end{tabular}

a Declares model and lists equations to be used in model; equations used depend on capabilities selected

b < filename.mdl > indicates that multiple versions of this file exist; appropriate version is used

c For multiple items on the same line, only one can be selected

d Conversion depends on data source (OWL .prn file, Aspen file, Speedup file, etc.) 


\subsection{OWL Interface with TWEAT}

Two improvements were made to the OWL part of the OWL-TWEAT interface. First, the OWL output file writer has been folded into the new architecture so the file can now be written for all OWL calculations. Previously, only the Base OWL model could write a TWEAT file.

Second, the options for using OWL and TWEAT together have been expanded. TWEAT can now be run in a Mac emulator on the Sun workstation where OWL resides. This makes it possible to access both OWL and TWEAT over the PNL network from a Windows PC; a Mac, or an engineering workstation. 


\subsection{Overall Tank Blending Scenario Analyses}

This section presents the results of an analysis of several blending scenarios for all of Hanford's high-level tank waste. Such scenarios could form the basis for an overall processing strategy for Hanford tank waste. These results suggest that it should be possible to develop a processing strategy capable of achieving Total Blend performance. Such a strategy is described in Section 6 .

\subsection{Overview of Previous Blending Work}

This analysis builds on the results of two previous blending studies, the FY93 Blend report $^{2}$, and the FY94 Blend Report ${ }^{b}$. The FY93 report described three basic blending models (Total Blend, Continuous Blend, and Discrete Blend) and the results of some blending calculations for small waste sets. It was determined that blending could substantially reduce the volume of glass required to vitrify high-level waste, and that the Total Blend (combining all high-level waste into a single blend) produced the minimum volume of glass. The FY94 report examined the effect of blend size (the number of tanks per blend), methods for solving the Discrete Blending problem, and heuristic strategies for formulating discrete blends. A summary of the key aspects of blending behavior is given in Appendix C. More detail can be found in the referenced reports.

\subsection{Basis for Blend Analyses}

The scenarios considered in this report are based on data and scenarios used in the Feed Processability Assessment Report (Lambert and Kim, 1994). The calculations described below were based on the fourteen waste streams (primarily by tank farm-A, AX, B, BX, BY, CC, $\mathrm{S}\left(5.27 \% \mathrm{Cr}_{2} \mathrm{O}_{3}\right)^{c}$, SX $\left.\left(14.5 \% \mathrm{Cr}_{2} \mathrm{O}_{3}\right), \mathrm{T}, \mathrm{TX}, \mathrm{TY}, \mathrm{U}, \mathrm{DSSF}, \mathrm{DST}\right)$ used by Lambert \& Kim. The waste composition file is given in Appendix D. (For information on the pretreatment and other assumptions leading to these compositions, see Lambert and Kim's report). Following Lambert and $\mathrm{Kim}$, the $\mathrm{P}_{2} \mathrm{O}_{5}$ limit was raised to $3 \%$ (mass fraction in the glass). The $\mathrm{Cr}_{2} \mathrm{O}_{3}$ limit used was $0.5 \%$. The same constraints were used for all calculations,

a Hoza, M. and J.G.H. Geeting. 1993. Blending Analysis Using the Optimal Waste Loading Model. TWRS-PP-93-058. Prepared for the Westinghouse Hanford Company by Pacific Northwest Laboratory, Richland, Washington.

- Hoza, M. 1994. Study of Potential Blending Strategies for Immobilization of Hanford High-Level Waste. TWRSPP-94-087. Prepared for the Westinghouse Hanford Company by Pacific Northwest Laboratory, Richland, Washington.

- The adjusted $\mathrm{Cr}_{2} \mathrm{O}_{3}$ compositions of Lambert and Kim were used. 
except Lambert and Kim's tank farm blends (which used different constraints for different waste types).

There were several reasons for selecting this set of waste data for the calculations here:

- Waste composition data by tank farm are generally considered to be more reliable than tank by tank data,

- Compositions for the high-level portions of those wastes were available, and

- Results could be compared with those of Lambert and Kim.

\subsection{Blending Scenario Results}

Several simple blending scenarios were evaluated and compared based on the waste composition data in Lambert and Kim. Table 5.1 summarizes the calculated results; each of the cases is described in the following sections.

Table 5.1. Blend Scenario Analysis Results

\begin{tabular}{|c|c|c|}
\hline Blend Scenario & $\begin{array}{c}\text { Total Glass Required } \\
\text { (million kg) }\end{array}$ & RunCode \\
\hline $\begin{array}{c}\text { Tank Farm Blends (as } \\
\text { determined by Lambert } \\
\text { and Kim) }\end{array}$ & 61 & N/A \\
\hline Cr-Metered Blend & 43.4 & L\&K11 \\
\hline Discrete Blend by farm & 37.6 & L\&K08 \\
\hline $\begin{array}{c}\text { Discrete Blend by } \\
\text { "tank" }\end{array}$ & 31.4 & L\&K10 \\
\hline Total Blend & 31.4 & L\&K02 \\
\hline
\end{tabular}

\subsubsection{Tank Farm Blends}

For the tank farm blends, Lambert and Kim estimated maximum reasonable glass waste loadings for each of the tank farms. They modified the constraints for each waste type as they felt appropriate based on Kim's glass formulation expertise. 


\subsubsection{Cr-Metered Blends}

For the $\mathrm{Cr}$-metered blends, the high-Cr waste in the $\mathrm{S}$ and $\mathrm{SX}$ farms was optimally distributed among the remaining 12 farms. This offered an improvement over the tank farm blends, but was not as effective as the discrete blends. There are two reasons for this. First, the discrete blend cases result in four blends; as the FY94 Blend Report showed, blending was more effective with more tanks per blend. Second, the waste was distributed based on one component of a 15component vector. In many cases, before enough high- $\mathrm{Cr}$ waste could be added to a farm to get to the $\mathrm{Cr}$ limit, the limit on another component was reached. Since $\mathrm{Cr}$ is the limiting component for the Total Blend, all blends must have $\mathrm{Cr}$ as the limiting constraint to achieve Total Blend performance. This phenomenon will limit the effectiveness of all heuristic blending strategies which make blending decisions based on a single component.

\subsubsection{Discrete Blend by Farm}

For the discrete blend by farm, the fourteen tank farm blends were optimally combined to form four blends using the OWL Discrete Blend Model. This strategy benefits from optimal blending and the formation of only four blends, but is limited because the high-Cr S and SX farm wastes can each go to only one blend. Thus, only two of the blends are limited by $\mathrm{Cr}$. The optimal blending combinations for this case are

(B, BY, SX),

$(A, B X, C, S, T)$,

(AX, U, DST), and

(TX, TY, DSSF).

\subsubsection{Discrete Blend by "Tank"}

This case is an approximation of blending by tank rather than of blended farms. Each farm was divided into "equivalent tanks", each with the same composition. Each farm had the same number of "equivalent tanks" as the number of actual tanks in that farm. Four blends were optimally formed with wastes from the 177 equivalent tanks; the total glass required was the same as for the Total Blend. The optimal assignments are given in Table 5.2. It is likely that other tank assignments could be found that would also provide Total Blend performance.

Tables 5.3 to 5.6 provide the calculated results for each blend. These results include the compositions of the blend, frit, and glass, waste loading, and mass of glass required. The calculated frit and glass compositions are not unique. The upper limit on $\mathrm{Cr}_{2} \mathrm{O}_{3}$ is the binding constraint for all four blends.

The overall results suggest that a processing and blending strategy, such as the one outlined in section 6 , should be able to achieve Total Blend performance. Of course, this analysis was done with "equivalent tanks" and would need to be 
Table 5.2 Optimal Assignments for Discrete Blend by "Tank"

\begin{tabular}{||l|l|l|l|l|l||}
\hline Farm & Total Tanks & $\begin{array}{l}\text { Tanks to } \\
\text { Blend 1 }\end{array}$ & $\begin{array}{l}\text { Tanks to } \\
\text { Blend 2 }\end{array}$ & $\begin{array}{l}\text { Tanks to } \\
\text { Blend 3 }\end{array}$ & $\begin{array}{l}\text { Tanks to } \\
\text { Blend 4 }\end{array}$ \\
\hline A & 6 & 2 & 1 & 2 & 1 \\
\hline AX & 4 & 0 & 2 & 0 & 2 \\
\hline B & 16 & 0 & 0 & 16 & 0 \\
\hline BX & 12 & 0 & 0 & 0 & 12 \\
\hline BY & 12 & 0 & 3 & 9 & 0 \\
\hline C & 16 & 1 & 2 & 10 & 3 \\
\hline S & 12 & 2 & 7 & 3 & 0 \\
\hline SX & 15 & 1 & 1 & 7 & 6 \\
\hline T & 16 & 0 & 4 & 1 & 11 \\
\hline TX & 18 & 3 & 4 & 0 & 11 \\
\hline TY & 6 & 1 & 2 & 1 & 2 \\
\hline U & 16 & 16 & 0 & 0 & 0 \\
\hline DSSF & 28 & 28 & 0 & 0 & 0 \\
\hline DST & 28 & 0 & 14 & 0 & 14 \\
\hline
\end{tabular}

repeated with actual tank compositions and masses. Other considerations, such as safety, logistics, and chemical compatibility, would certainly need to be factored into the process of developing a retrieval sequence consistent with optimal blend results. A process for accommodating necessary considerations is presented in Section 6.

\subsubsection{Total Blend}

The Total Blend case involves combining all waste into a single blend, then determining the required glass for that blend. The Total Blend is logistically impossible, but it serves as a useful reference case against which to compare other strategies, since it produces the minimum possible amount of glass. 
Table 5.3 Calculated Results for Blend 1

BLEND BI Compositions (Mass Fractions)

$\begin{array}{llll}\text { Component } & \text { Blend } & \text { Frit } & \text { Glass } \\ \text { SIO2 } & 0.1498 & 0.6620 & 0.4200 \\ \text { B2O3 } & 0.0000 & 0.2380 & 0.1256 \\ \text { NA2O } & 0.3473 & 0.0000 & 0.1641 \\ \text { LI2O } & 0.0000 & 0.0569 & 0.0300 \\ \text { CAO } & 0.0046 & 0.0000 & 0.0022 \\ \text { MGO } & 0.0000 & 0.0000 & 0.0000 \\ \text { FE2O3 } & 0.0874 & 0.0000 & 0.0413 \\ \text { AL2O3 } & 0.1523 & 0.0431 & 0.0947 \\ \text { ZRO2 } & 0.0191 & 0.0000 & 0.0090 \\ \text { OTHER } & 0.2394 & 0.0000 & 0.1131 \\ \text { CR2O3 } & 0.0106 & 0.0000 & 0.0050 \\ \text { F } & 0.0016 & 0.0000 & 0.0007 \\ \text { P2O5 } & 0.0175 & 0.0000 & 0.0083 \\ \text { SO3 } & 0.0030 & 0.0000 & 0.0014 \\ \text { NOBMET } & 0.0000 & 0.0000 & 0.0000\end{array}$

Mass $(\mathrm{kg})$ of Waste Oxide in Blend 1569167.90

Mass Fraction of Waste in High-Level Glass 0.472

Number of High-Level Glass Logs Required 885.6

Mass (kg) Glass Required $\quad 3321067.7$

Calculated Glass Properties

Property

Viscosity, Pas

Electrical Conductivity, $\mathrm{s} / \mathrm{m}$

Release of Boron by MCC, $\mathrm{g} / \mathrm{m} 2$

Release of Boron by PCT, $g / \mathrm{m} 2$

Release of $\mathrm{Li}$ by PCT, $g / \mathrm{m} 2$

Release of $\mathrm{Na}$ by PCT, $g / \mathrm{m} 2$

Liq $\mathrm{T}$ - Clinopyroxene, deg $\mathrm{C}$

Liq $T$ - Spinel, deg $C$

Liq T - Zr-contg Xstals, deg C 723.21
Value

3.56

44.98

26.85

2.00

1.39

1.00

801.49

878.55

$\begin{array}{rr}\text { Lower } & \text { Upper } \\ \text { Limit } & \text { Limit } \\ 2.0 & 10.0 \\ 10.0 & 100.0 \\ 9999.0 \\ 8.2 \\ 4.8 \\ 6.6 \\ 1050.0 \\ 1050.0 \\ 1050.0\end{array}$


Table 5.4 Calculated Results for Blend 2

$\begin{array}{lccc}\text { BLEND B2 } & \text { Compositions } & \\ \text { Component } & \text { Blend } & \text { Frit } & \\ \text { SIO2 } & 0.0723 & 0.6025 & \text { Glass } \\ \text { B2O3 } & 0.0011 & 0.1173 & 0.4368 \\ \text { NA2O } & 0.3511 & 0.1454 & 0.0810 \\ \text { LI2O } & 0.0000 & 0.0436 & 0.2097 \\ \text { CAO } & 0.0142 & 0.0000 & 0.0300 \\ \text { MGO } & 0.0007 & 0.0000 & 0.0044 \\ \text { FE2O3 } & 0.0923 & 0.0000 & 0.0002 \\ \text { AL2O3 } & 0.1180 & 0.0912 & 0.0289 \\ \text { ZRO2 } & 0.1100 & 0.0000 & 0.0995 \\ \text { OTHER } & 0.2403 & 0.0000 & 0.0344 \\ \text { CR2O3 } & 0.0160 & 0.0000 & 0.0751 \\ \text { F } & 0.0062 & 0.0000 & 0.0050 \\ \text { P2O5 } & 0.0339 & 0.0000 & 0.0019 \\ \text { SO3 } & 0.0037 & 0.0000 & 0.0106 \\ \text { NOBMET } & 0.0002 & 0.0000 & 0.0012 \\ & & & 0.0001\end{array}$

Mass $(\mathrm{kg})$ of Waste Oxide in Blend $\quad 2546010.40$

Mass Fraction of Waste in High-Level Glass 0.313

Number of High-Level Glass Logs Required 2172.0

Mass (kg) Glass Required

8144888.8

Calculated Glass Properties

$\begin{array}{lrrr}\text { Property } & \text { Value } & \begin{array}{r}\text { Lower } \\ \text { Limit }\end{array} & \begin{array}{r}\text { Upper } \\ \text { Limit }\end{array} \\ \text { Viscosity, Pas } & 4.47 & 2.0 & 10.0 \\ \text { Electrical Conductivity, S/m } & 60.15 & 10.0 & 100.0 \\ \text { Release of Boron by MCC, g/m2 } & 21.59 & & 9999.0 \\ \text { Release of Boron by PCT, g/m2 } & 1.58 & & 8.2 \\ \text { Release of Li by PCT, g/m2 } & 1.00 & & 4.8 \\ \text { Release of Na by PCT, g/m2 } & 1.00 & & 6.6 \\ \text { Liq T - Clinopyroxene, deg C } 791.65 & & 1050.0 \\ \text { Iiq T - Spinel, deg C } 834.92 & & 1050.0 \\ \text { Liq T -.Zr-contg Xstals, deg C } 770.35 & & 1050.0\end{array}$


Table 5.5 Calculated Results for Blend 3

$\begin{array}{lccc}\text { BLEND B3 } & \text { Compositions } & \\ \text { Component } & \text { Mlend } & \text { Frit } & \text { Glass } \\ \text { SIO2 } & 0.0324 & 0.7215 & 0.5168 \\ \text { B203 } & 0.0000 & 0.0711 & 0.0500 \\ \text { NA20 } & 0.3358 & 0.1438 & 0.2008 \\ \text { LI20 } & 0.0000 & 0.0427 & 0.0300 \\ \text { CAO } & 0.0326 & 0.0000 & 0.0097 \\ \text { MGO } & 0.0000 & 0.0000 & 0.0000 \\ \text { FE203 } & 0.1127 & 0.0209 & 0.0482 \\ \text { AL2O3 } & 0.0906 & 0.0000 & 0.0269 \\ \text { ZRO2 } & 0.0516 & 0.0000 & 0.0153 \\ \text { OTHER } & 0.3443 & 0.0000 & 0.1023 \\ \text { CR2O3 } & 0.0168 & 0.0000 & 0.0050 \\ \text { F } & 0.0068 & 0.0000 & 0.0020 \\ \text { P2O5 } & 0.0574 & 0.0000 & 0.0171 \\ \text { SO3 } & 0.0023 & 0.0000 & 0.0007 \\ \text { NOBMET } & 0.0000 & 0.0000 & 0.0000\end{array}$

Mass $(\mathrm{kg})$ of Waste Oxide in Blend $\quad 3486148.20$

Mass Fraction of Waste in High-Level Glass 0.297

Number of High-Level Glass Logs Required 3129.5

Mass (kg) Glass Required $1.1736 \mathrm{E}+7$

Calculated Glass Properties

$\begin{array}{lrrr}\text { Property } & \begin{array}{r}\text { Vower } \\ \text { Value } \\ \text { Viscosity, Pas }\end{array} & \begin{array}{r}\text { Upper } \\ \text { Limit }\end{array} & \begin{array}{r}\text { Limit } \\ 10.0\end{array} \\ \text { Electrical Conductivity, S/m } & 56.53 & 10.0 & 100.0 \\ \text { Release of Boron by MCC, g/m2 } & 24.72 & & 9999.0 \\ \text { Release of Boron by PCT, g/m2 } & 6.45 & 8.2 \\ \text { Release of Li by PCT, g/m2 } & 4.80 & 4.8 \\ \text { Release of Na by PCT, g/m2 } & 4.79 & 6.6 \\ \text { Liq T - Clinopyroxene, deg C } 799.70 & & 1050.0 \\ \text { Liq T - Spinel, deg C } 827.18 & & 1050.0 \\ \text { Liq T - Zr-contg Xstals, deg C } 677.09 & & 1050.0\end{array}$


Table 5.6 Calculated Results for Blend 4

$\begin{array}{lccc}\text { BLEND B4 } & \text { Compositions } & \text { (Mass } & \text { Fractions) } \\ \text { Component } & \text { Blend } & \text { Frit } & \text { Glass } \\ \text { SIO2 } & 0.1231 & 0.8105 & 0.4200 \\ \text { B2O3 } & 0.0006 & 0.1150 & 0.0500 \\ \text { NA20 } & 0.3385 & 0.0000 & 0.1923 \\ \text { LI20 } & 0.0000 & 0.0694 & 0.0300 \\ \text { CAO } & 0.0059 & 0.0000 & 0.0034 \\ \text { MGO } & 0.0003 & 0.0000 & 0.0002 \\ \text { FE2O3 } & 0.0793 & 0.0000 & 0.0450 \\ \text { AL2O3 } & 0.1243 & 0.0050 & 0.0728 \\ \text { ZRO2 } & 0.0580 & 0.0000 & 0.0330 \\ \text { OTHER } & 0.2699 & 0.0000 & 0.1533 \\ \text { CR2O3 } & 0.0088 & 0.0000 & 0.0050 \\ \text { F } & 0.0043 & 0.0000 & 0.0024 \\ \text { P2O5 } & 0.0516 & 0.0000 & 0.0293 \\ \text { SO3 } & 0.0037 & 0.0000 & 0.0021 \\ \text { NOBMET } & 0.0001 & 0.0000 & 0.0000\end{array}$

Mass $(\mathrm{kg})$ of Waste Oxide in Blend

4690973.50

Mass Fraction of Waste in High-Level Glass 0.568

Number of High-Level Glass Logs Required 2201.9

Mass (kg) Glass Required

8256975.6 .

Calculated Glass Properties

$\begin{array}{lrrr}\text { Property } & \begin{array}{r}\text { Lower } \\ \text { Value } \\ 4.20\end{array} & \begin{array}{r}\text { Upper } \\ \text { Limit }\end{array} & \begin{array}{r}\text { Limit } \\ \text { Viscosity, PaS } \\ \text { Electrical Conductivity, S/m } \\ 60.65\end{array} \\ \text { Release of Boron by MCC, g/m2 } & 24.91 & 10.0 & 100.0 \\ \text { Release of Boron by PCT, g/m2 } & 2.41 & 9999.0 \\ \text { Release of Li by PCT, g/m2 } & 1.62 & 8.2 \\ \text { Release of Na by PCT, g/m2 } & 1.47 & 4.8 \\ \text { Liq T - Clinopyroxene, deg C } 856.33 & 6.6 \\ \text { Liq T - Spinel, deg C } 863.55 & 1050.0 \\ \text { Liq T - Zr-contg Xstals, deg C } 759.75 & & 1050.0 \\ \end{array}$




\subsection{Proposed Retrieval, Processing, and Blending Strategy}

This section presents an overall processing strategy for Hanford tank waste and an approach for developing and evaluating candidate processing strategies. The processing strategy addresses retrieval, pretreatment, and vitrification of high-level and low-level waste. It uses a comprehensive blending approach based on three years of waste blending analysis work to greatly reduce the number of high-level waste feed streams and to achieve a minimal volume of high-level waste glass with sufficient flexibility to meet safety, processing, and logistics constraints.

The discussion is presented in the next three sections. The motivation for the strategy and the benefits from its implementation are discussed in the first section; a description of the strategy is presented in the following section. Finally, an approach for developing and evaluating candidate strategies is presented.

\subsection{Motivation for Processing Strategy}

A processing strategy making effective use of waste blending has several compelling advantages:

- The strategy can potentially reduce the number of glass logs required for highlevel waste to the Total Blend number, while still meeting all safety, processing, and logistics constraints. The Total Blend number of logs is the minimum number that can be achieved and could be as much as $25^{\mathrm{a}}-50^{\mathrm{b}} \%$ less than the number of logs required if no blending were done.

- The strategy can reduce the number of feeds to HLW vitrification to a handful (about four to six). Rather than having to deal with a large number of waste compositions in a large composition space (see Figure 6.1), a much smaller number of waste compositions would be targeted. These compositions could be determined such that the overall volume of waste glass is minimal, resulting in a small number of distinct compositions, each with its associated uncertainty, or such that the final waste compositions are clustered in a single composition region (near the Total Blend composition).

In the FY94 blending study (report TWRSPP-94-087), the blending of 87 tanks for which compositions were available was examined. For those tanks, vitrifying a blend of all tanks required $25.3 \%$ fewer logs than vitrifying each waste separately.

' In Section 4 of this report, a reduction of almost $50 \%$ was achieved relative to blending and vitrifying by tank farm. 
uoln!

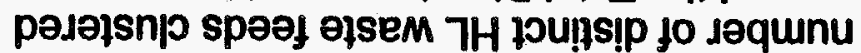

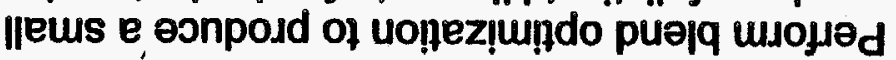

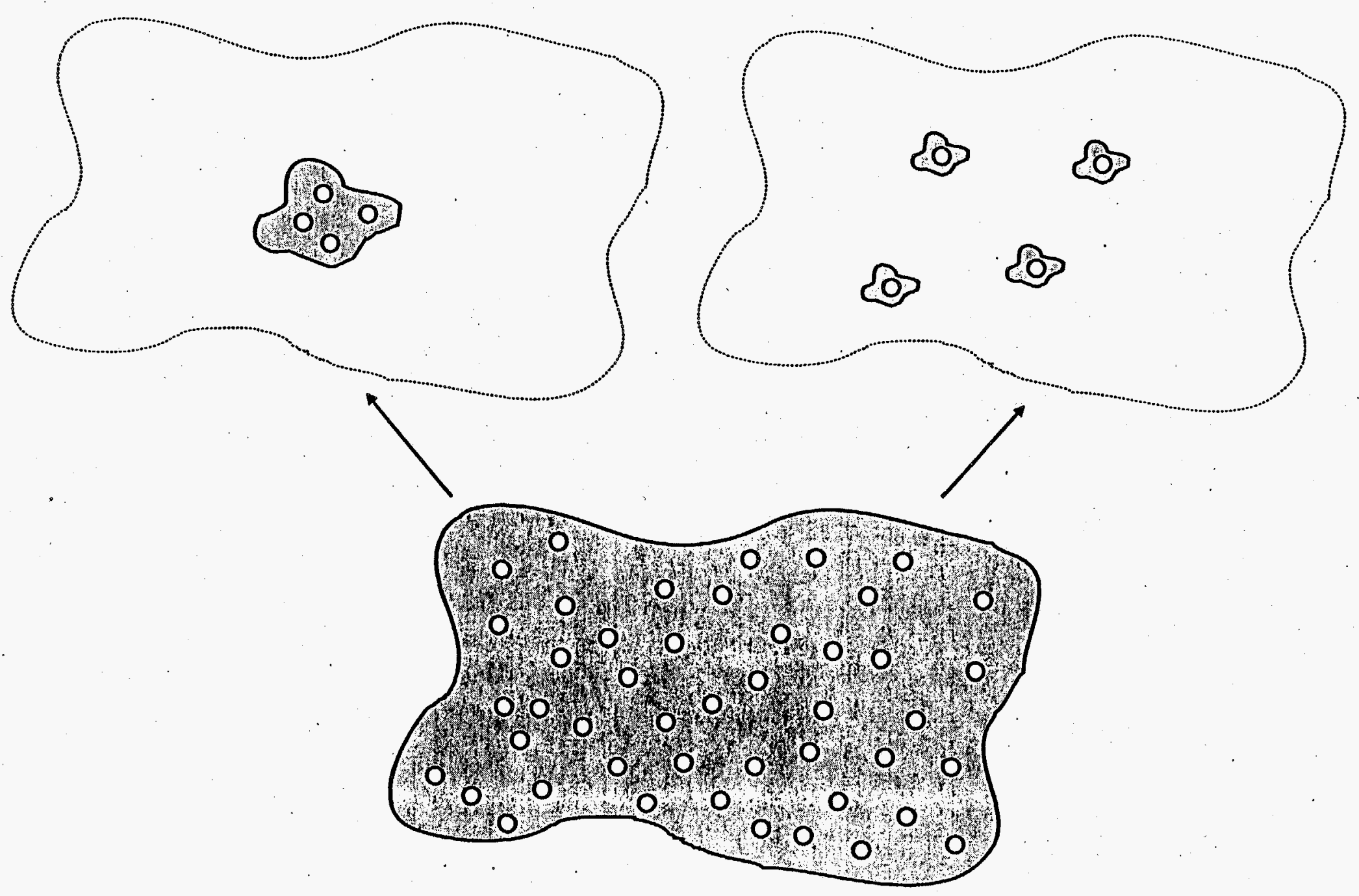

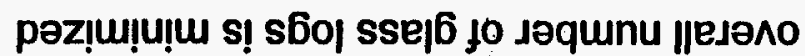

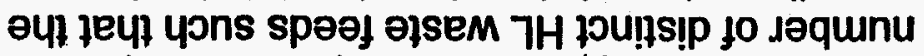

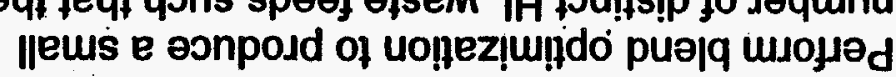


Reducing the number of high-level waste feeds offers several advantages:

- Glass formulation and feed rheology experimental work can focus on a small number of targeted compositions, avoiding the need to try to model either a large number of compositions or any composition within a large composition region. Behavior within the targeted regions could be better understood and more effectively modeled.

- The number of distinct glasses that need to be qualified would be reduced.

- Since there would be far fewer waste feeds to deal with, sampling and chemical analysis could be used to a greater extent to reduce the uncertainty in waste feed compositions.

- The strategy can provide a firm technical basis for making TWRS decisions from a system life cycle cost perspective. It can help identify:

- which components should be targeted for removal in pretreatment (which are most cost effective)?

- what retrieval/processing facilities/designs are most constraining to implementation of a comprehensive processing strategy (transfer lines, lag storage, new tanks, retrieval annexes)? Which upgrades would be most cost effective?

\subsection{Description of Processing Strategy}

The proposed processing strategy uses extensive optimized blending to reduce the number of high-level waste feeds and minimize the volume of high-level glass produced. Blending of low-level wastes is also addressed.

The strategy is depicted in Figure 6.2. As tanks are retrieved and pretreated, the high-level portions would be collected in HL-Waste holding tanks. For the purpose of illustration sixteen tanks are shown. All the high-level waste produced during a certain time interval would end up in a single HL-Waste holding tank. It would contain the high-level portions of all the tanks retrieved and processed during that time interval.

Assume for the moment that all sixteen tanks are available for blending. One could then perform a discrete blending optimization that would produce (for this example) four HL-Feed Blends. This optimization could be performed such that it would either result in the minimal volume of glass (likely to be the Total-Blend amount) or a set of wastes clustered in composition around the Total Blend composition (which may or may not achieve Total Blend performance). 


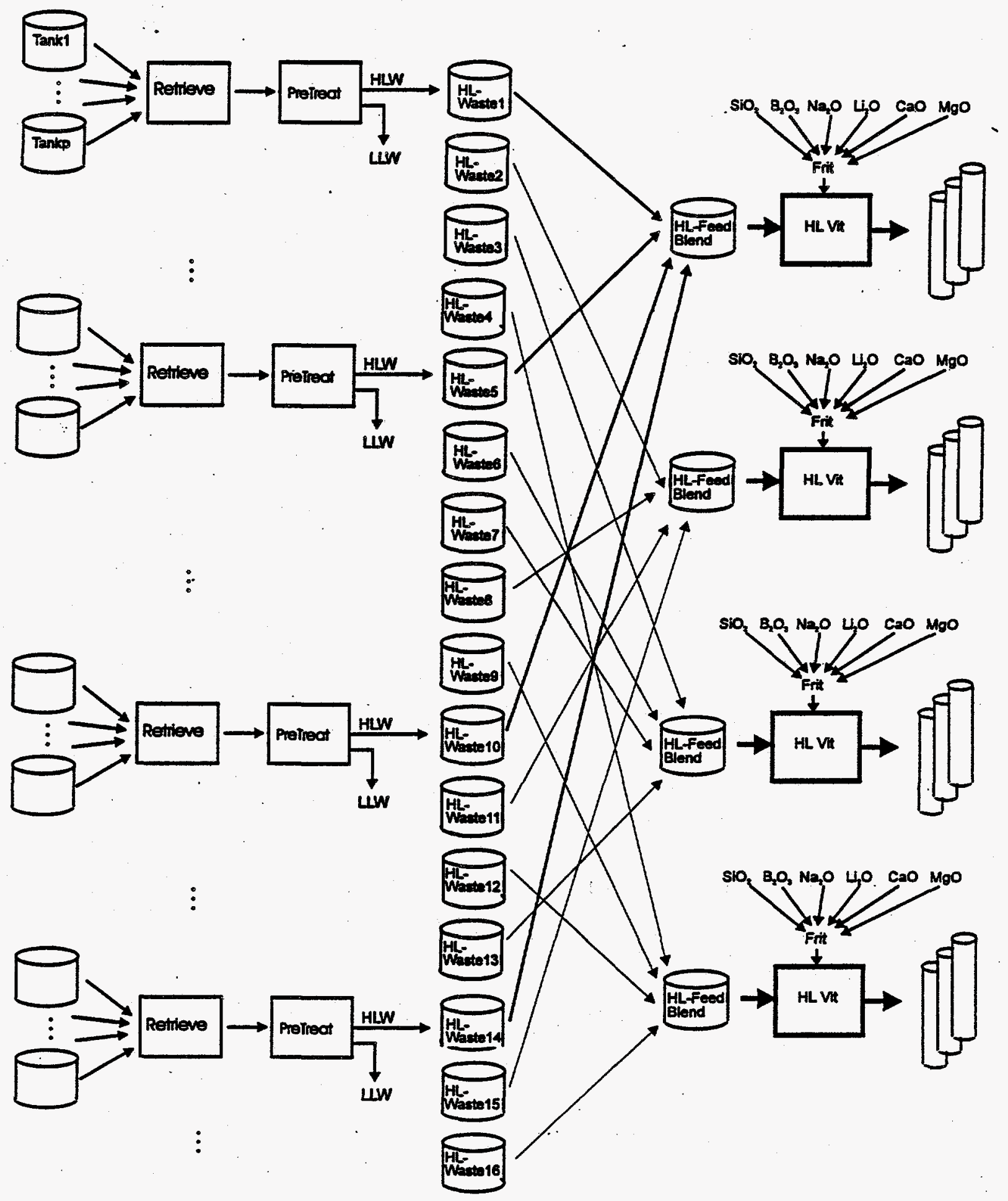

Figure 6.2 Schematic Representative of Proposed TWRS Processing Strategy 
Of course, not all the wastes will be available at the same time. But this analysis can help schedule tank retrieval such that the necessary wastes are available. Note the bold lines leading to the first HL-Feed Blend tank. Having identified that these HLWaste tanks are optimally blended to form the first HL-Feed Blend, one could then identify which Hanford waste tanks went into each of the HL-Waste tanks. Those Hanford waste tanks would be retrieved and processed first. One would proceed similarly for each of the HL-Feed Blends. The methods for assigning tanks to one of the sixteen HL-Waste groups is discussed in the next section.

But what about low-level waste? Where does it fit into the strategy? Since the volume of low-level waste is much greater than that of high-level waste, one is not able to collect LLW for later blending. Rather, one should use the incidental blending encountered in retrieving and processing tanks to achieve LLW blending objectives. Once the tanks are assigned to a retrieval group, the ordering within the group could be determined to meet low-level blending objectives. If, however, most low-level waste is limited by $\mathrm{Na}_{2} \mathrm{O}$, there may not be as much motivation for blending low-level wastes.

\subsection{Description of Implementation and Evaluation Strategy}

The issue addressed in this section is how to formulate and evaluate specific implementations of the strategy such that the objectives of the strategy, as well as safety, logistics, and programmatic objectives are met. The process is iterative and consists of the following steps:

(iterate on 1-5 until done)

1. Specify the number of HL-Blend tanks and the number of HL-Feed Blends.

2. Assign each tank to one of the HL-Blend groups, distributing them so each tank group has about the same mass or the same number of tanks. This can be done manually or using a rule-based expert system. Initial assignments may use general rules of thumb (e.g., divide each tank farm into at least three groups); subsequent assignments can be based on knowledge about how well previous assignments met system objectives.

3. Use the OWL Tank Waste Blending Model to calculate the performance of the system as defined and optimize the formation of the HL Feed blends from the HL-Blends. If the performance of the system for the collection of tank groups is unacceptable, repeat step 2 to obtain new groups. Calculated glass formulations could be examined with TWEAT to ensure sufficient operational flexibility.

4. If the system provides acceptable performance (target: Total Blend), develop retrieval sequences consistent with appropriate safety, scheduling, chemical compatibility, and other considerations (including low-level waste blending). 
Swapping tanks between HL-Blend groups that feed the same HL Feed blend is acceptable. This assignment could be done manually, or using an expert system.

5. Use WHC tank processing logistics models to test the sequences developed in steps 14 . If processing problems are found, repeat steps $2-4$. If necessary, repeat steps 1-4. Processing problems could result from assumptions or decisions which limit processing flexibility. This analysis could suggest revisiting some of those decisions.

When this process is successfully completed, one will have determined a processing and blending architecture, a retrieval sequence, compositions of a small number of high-level waste feeds to be vitrified, and calculated glass volumes for those compositions. This specific strategy can then serve as the basis for engineering and experimental development. 


\subsection{Conclusions and Recommendations}

This report presented the results of OWL development and analysis work in

FY 95. The following were addressed:

- Upgrade of OWL property models. The models are now consistent with the latest CVS report property and uncertainty models.

- Upgrade of OWL model architecture. The modular architecture uses core model files for all models, has a single file interface to TWEAT for all models, facilitates interoperability with other Hanford models, and provides a mechanism for use of site tank characterization data.

- Analysis of high-level blending approaches. Several simple approaches were evaluated, one of which achieved Total Blend performance.

- Presentation of an overall Hanford processing and blending strategy. The strategy could minimize the required high-level waste glass volume, greatly reduce the number of distinct high-level wastes to be vitrified, and provide a consistent technical basis for making system-wide decisions.

Future development work should address the following:

- Adapt OWL to more closely mimic the approach a glass chemist uses in formulating glasses.

- Adapt OWL for use in formulating glasses for a high-temperature melter.

- Develop a version of OWL for low-level glass formulation.

- Complete the development of the interface to tank inventory data. This would include upgrading the simple pretreatment module from the Process Chemistry Model.

- Complete the development of the interfaces to related Hanford models, such as the Aspen pretreatment model and the Arena logistics model. 


\subsection{References}

Hrma, P.R., G.F. Piepel, et al. 1994. Property/Composition Relationships for Hanford High-Level Waste Glasses Melting at 1150 C. PNL-10359, Volumes 1 and 2, Pacific Northwest Laboratory, Richland, Washington.

Lambert, S.L., D.S. Kim, et al. 1994. Tank Waste Remediation System High-Level Waste Feed Processability Assessment Report. WHC-SP-1143, Westinghouse Hanford Company, Richland, Washington. 


\section{APPENDLX A}

Glass Property Model Coefficients 


\section{Appendix A}

\section{Glass Property Model Coefficients}

* Viscosity Model Coefficients

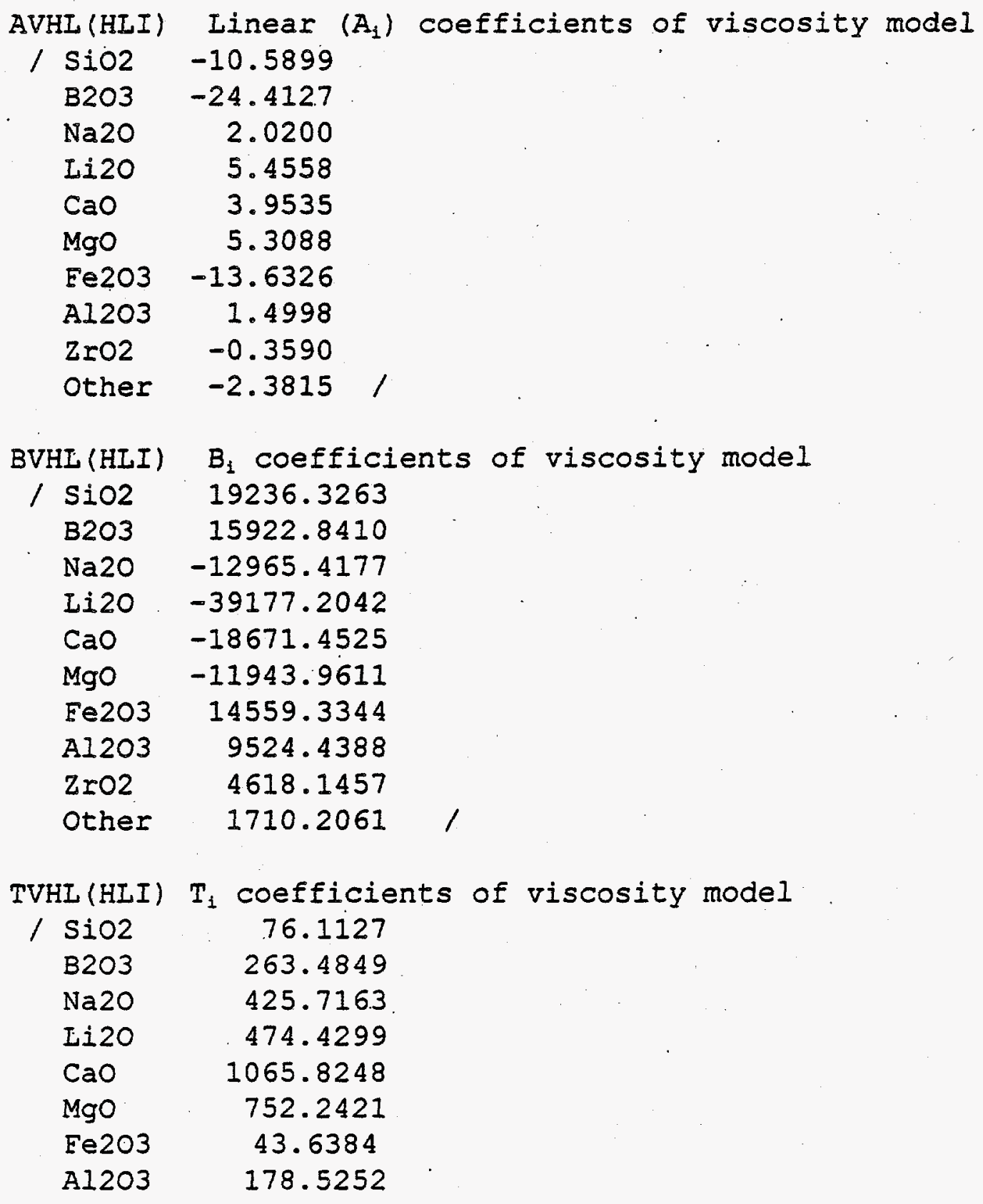

TVHL(HLI) $T_{1}$ coefficients of viscosity model

$\begin{array}{lr}\text { / } \mathrm{SiO} 2 & 76.1127 \\ \mathrm{~B} 2 \mathrm{O} 3 & 263.4849 \\ \mathrm{Na} 20 & 425.7163 \\ \mathrm{Ei} 2 \mathrm{O} & 474.4299 \\ \mathrm{CaO} & 1065.8248 \\ \mathrm{MgO} & 752.2421 \\ \mathrm{Fe} 203 & 43.6384 \\ \mathrm{Al} 203 & 178.5252\end{array}$

A.1 
$\mathrm{ZrO2} \quad 540.5086$

Other $270.7406 /$

A. 2 
* Electrical Conductivity Model Coefficients

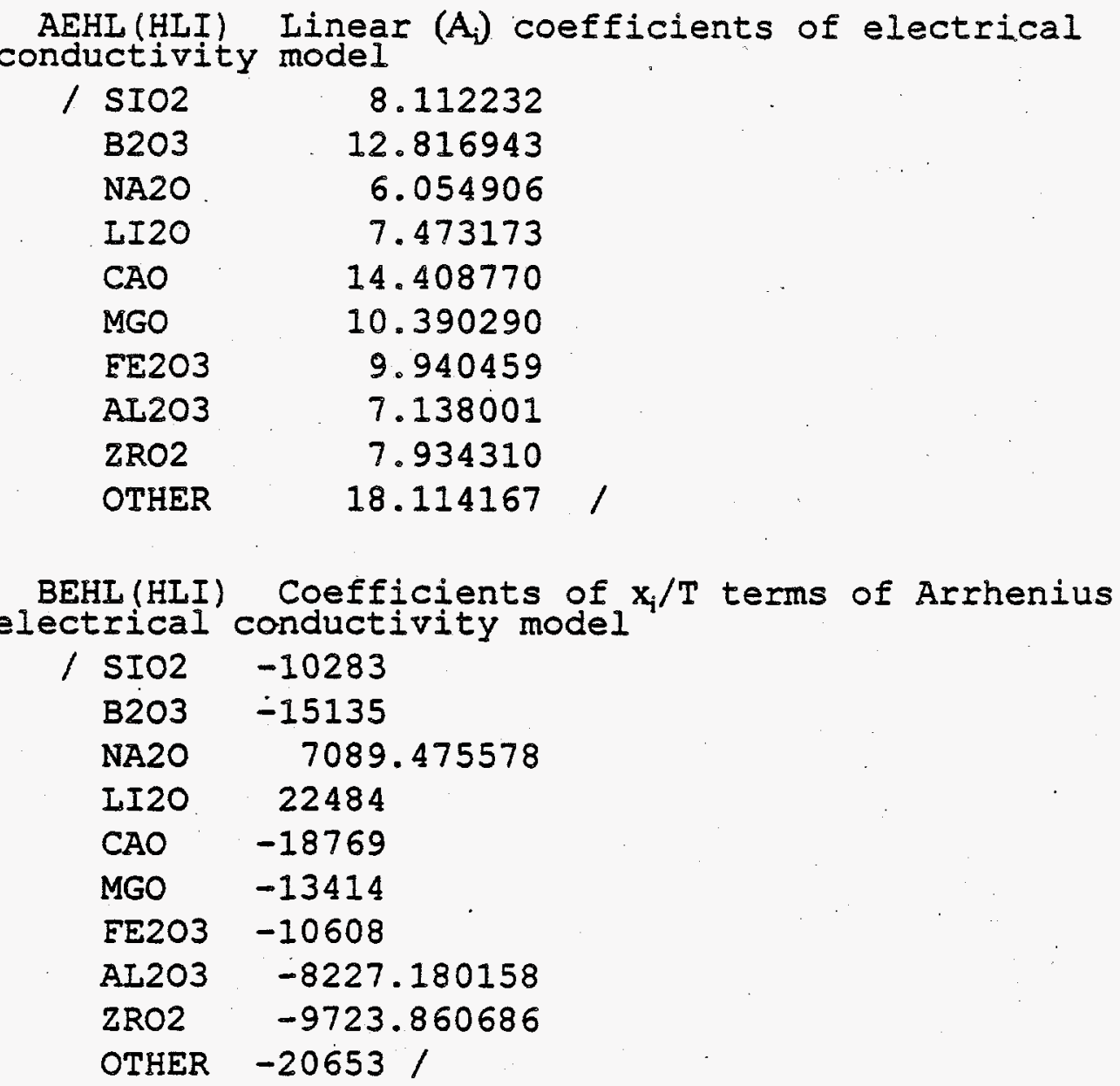


* Durability Modei Coefficients, MCC-1, Boron

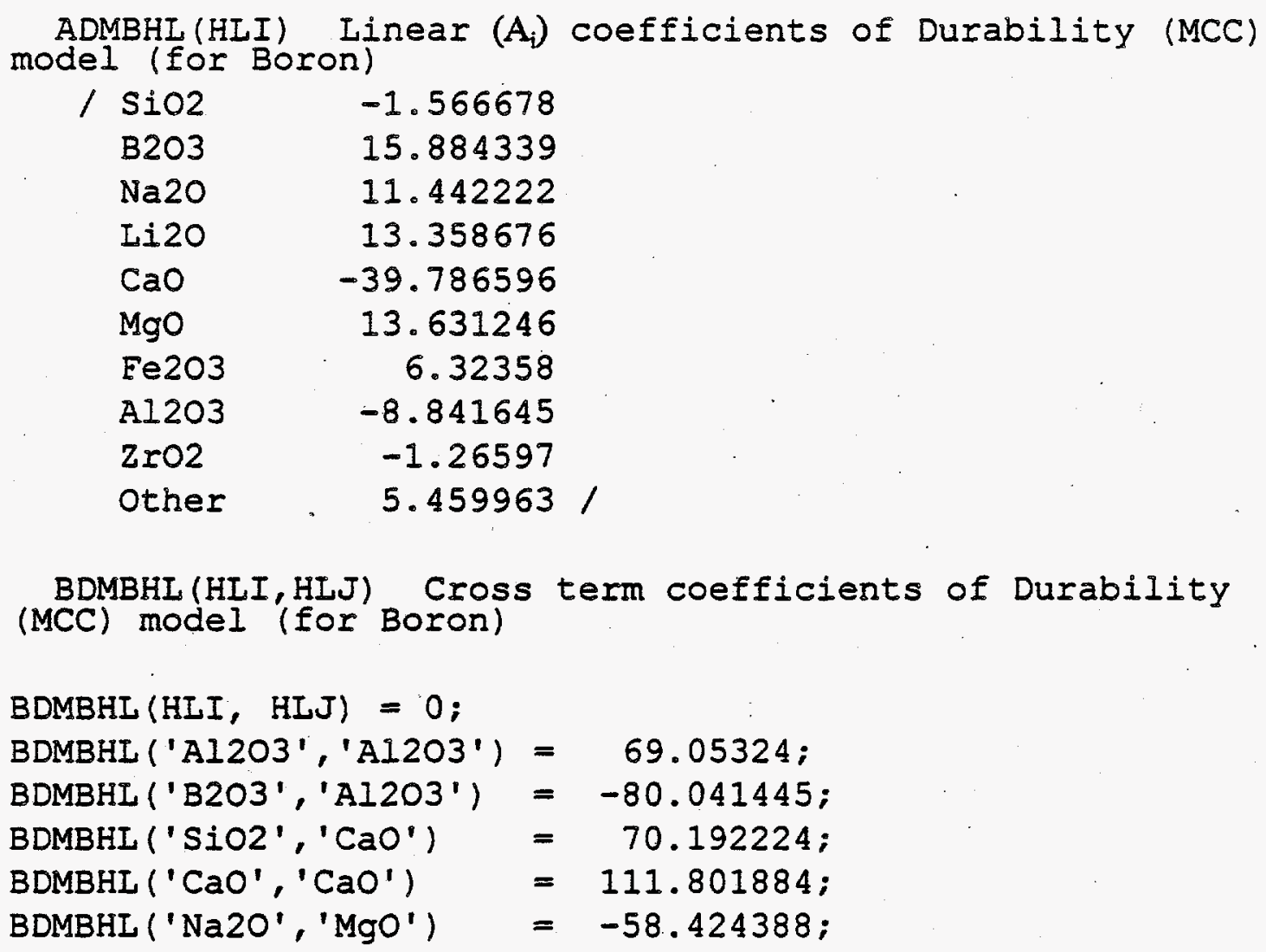

BDMBHL (HLI, HLJ) Cross term coefficients of Durability (MCC) model (for Boron)

BDMBHI (HII, HIJ) $=0$;

BDMBHL ('Al203','Al203') = 69.05324;

BDMBHL ('B203','AI203') = -80.041445 ;

BDMBHL ('SiO2', 'CaO') = 70.192224;

BDMBHL ('CaO', 'CaO') $=111.801884 ;$

BDMBHL('Na20', 'MgO')= $\quad=58.424388$; 
* Durability Model Coefficients, PCT, Boron

ADPBHL (HLI) Linear $\left(\mathrm{A}_{i}\right)$ coefficients of Durability (PCT) model (for Boron)

$\begin{array}{lr}\text { / } \mathrm{SiO} 2 & -4.379969 \\ \mathrm{~B} 203 & -3.080004 \\ \mathrm{Na} 20 & 21.440509 \\ \mathrm{Li} 2 \mathrm{O} & 24.173993 \\ \mathrm{C} \mathrm{C} & 14.06971 \\ \mathrm{MgO} & -49.728818 \\ \mathrm{Fe} 203 & -1.311381 \\ \mathrm{~A} 203 & -39.578233 \\ \mathrm{ZrO} 2 & -11.416302 \\ \text { Other } & 4.208259\end{array}$

BDPBHL(HLI, HLJ) Cross term coefficients of Durability
(PCT) model for Boron

$\mathrm{BDPBHL}(\mathrm{HLI}, \mathrm{HLJ})=0$;

BDPBHL ('Al203', 'Al203') = 104.218254 ;

BDPBHL ('B203', 'B203') $=76.658177$;

BDPBHL ('SiO2','MgO') = 117.171887 ;

BDPBHL (' $\mathrm{Na2O}$ ', 'CaO') $=-120.88413$;

BDPBHL ('B203', 'CaO') $=-91.140649$;

BDPBHL ('MgO','ZrO2') = 122.085204 ; 
* Durability Model Coefficients, PCT, Lithium

ADPLHL (HLI) Iinear ( $\left.A_{i}\right)$ coefficients of Durability (PCT) model (for $L i$ )

$\begin{array}{lr}\text { / } \mathrm{SiO} 2 & -2.951747 \\ \mathrm{~B} 2 \mathrm{O} 3 & -5.82881 \\ \mathrm{Na} 2 \mathrm{O} & 18.742069 \\ \mathrm{Li} 2 \mathrm{O} & 18.904144 \\ \mathrm{CaO} & 14.066675 \\ \mathrm{MgO} & 14.47951 \\ \mathrm{Fe} 203 & -5.631035 \\ \mathrm{~A} 203 & -31.380797 \\ \text { ZrO2 } & -10.211191 \\ \text { Other } & 2.652327\end{array}$

BDPLHL (HII, HLJ) Cross term coefficients of Durability (PCT) model for $\mathrm{Li}$

BDPLHL ( $\mathrm{HLI}, \mathrm{HLJ})=0$;

BDPLHL ('Al203', 'A1203') $=94.025208$;

BDPLHL('B203','B2O3') $=76.945946$;

BDPLHL ('MgO', 'Al203') $=-134.707636$;

BDPLHL ('B2O3', ${ }^{\prime} \mathrm{CaO}$ ') $=-94.6921$;

BDPLHL ('Na20', 'CaO') $=-81.928013$;

BDPLHL ('Na20', 'Al203') $=-43.351121$;

BDPLHL ('Fe2O3', 'Al203') = 75.988423; 
* Durability Model Coefficients, PCT, Sodium

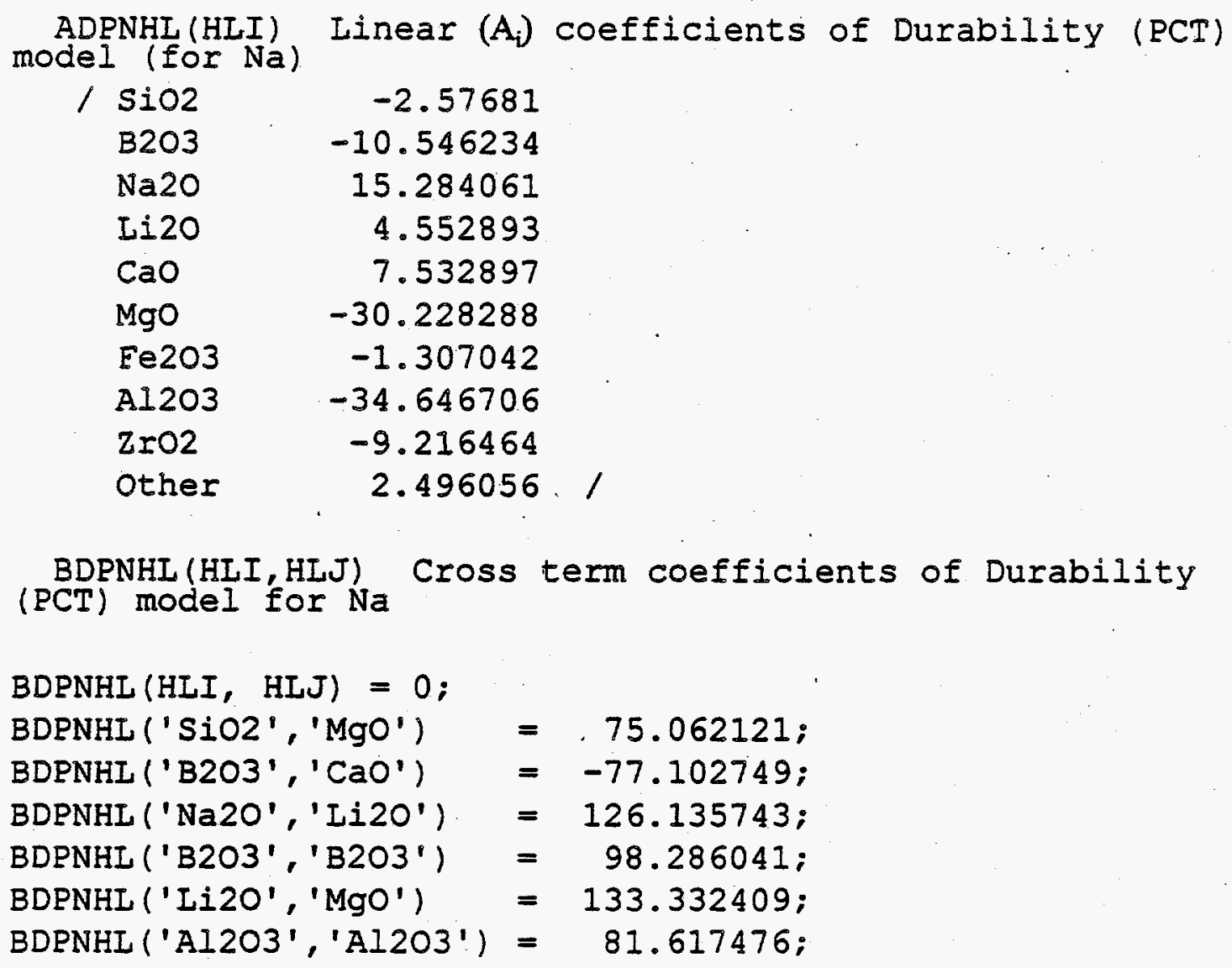

BDPNHL (HLI, HLJ) Cross term coefficients of Durability (PCT) model for $\mathrm{Na}$ 
* Linear Liquidus Temperature Model coefficients

ATLClHL (HLI) Iinear $\left(A_{i}\right)$ coefficients of liquidus temp model for clinopyroxene

$\begin{array}{lr}\text { / } \mathrm{SiO2} & 955.648709 \\ \mathrm{~B} 203 & 314.718016 \\ \mathrm{Na} 20 & 38.828095 \\ \mathrm{Li} 20 & -207.052312 \\ \mathrm{CaO} & 1372.437773 \\ \mathrm{MgO} & 2387.619243 \\ \mathrm{Fe} 203 & 1506.687256 \\ \mathrm{~A} 203 & 1319.781389 \\ \text { ZrO2 } & 1844.501017 \\ \text { Other } & 1357.404454\end{array}$

ATLSpHL(HLI) Linear $\left(A_{i}\right)$ coefficients of liquidus temp model for spinel

$\begin{array}{lr}\text { / } \mathrm{SiO2} & 989.305474 \\ \mathrm{~B} 203 & 666.419006 \\ \mathrm{Na} 20 & 3.772076 \\ \mathrm{Li} 20 & -128.772539 \\ \mathrm{CaO} & 1366.211045 \\ \mathrm{MgO} & 2830.582448 \\ \mathrm{Fe} 203 & 2256.001202 \\ \mathrm{~A} 203 & 1735.02572 \\ \text { ZrO2 } & 928.109425 \\ \text { Other } & 1005.555325\end{array}$

ATLZrHL (HII) Linear $\left(A_{1}\right)$ coefficients of liquidus temp model for $\mathrm{Zr}$-containing crystals

$\begin{array}{lr}\text { / } \mathrm{SiO} 2 & 753.776337 \\ \mathrm{~B} 2 \mathrm{O} 3 & 1095.830409 \\ \mathrm{Na} 20 & 74.313813 \\ \mathrm{Li} 20 & -956.393494 \\ \mathrm{CaO} & 886.76338 \\ \mathrm{MgO} & 2458.467726 \\ \mathrm{Fe} 203 & 1461.039068 \\ \mathrm{Al} 203 & 1138.061069 \\ \text { ZrO2 } & 4541.994125 \\ \text { Other } & 657.994105\end{array}$

A.8 


\section{APPENDIX B}

\section{Covariance Matrices for OWL Uncertain Model}




\section{Appendix B}

\section{Covariance Matrices for OWL Uncertainty Model}

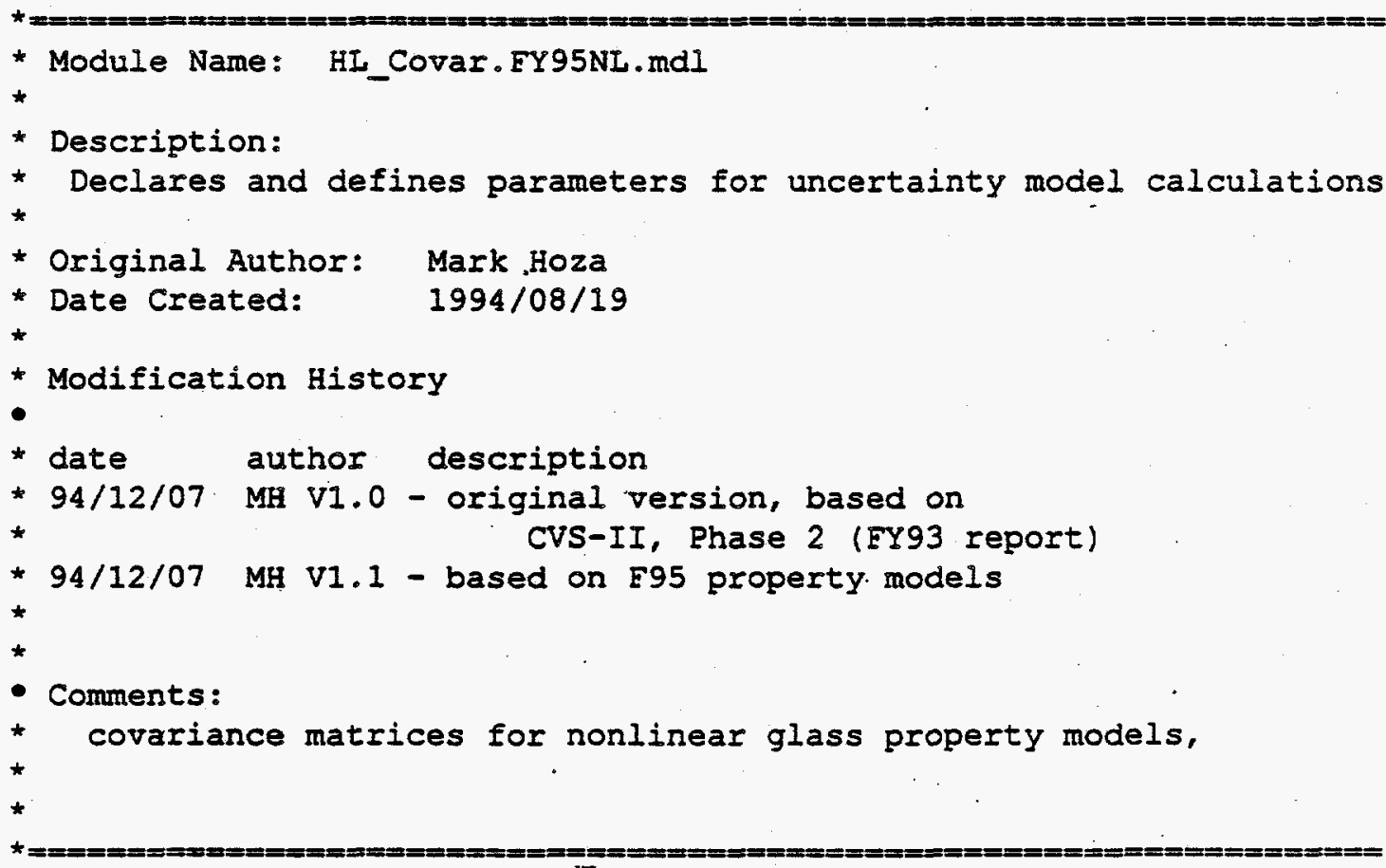

* Declare and define parameters for uncertainty calculation

SCALARS

SDVHL std dev (sqrt variance) of viscosity model

CIVHL $95 \%$ confidence interval multiplier viscosity for model /1.646407/

CBVHL $95 \%$ confidence band multiplier for viscosity model /6.3.64486/

UMltVHL Uncertainty multiplier (=CI or CB) assigned at runtime

SDEHL std dev (sqrt variance) of E-Cond model

CIEHL $95 \%$ confidence interval multiplier for E-Cond model

CBEHI, $95 \%$ confidence band multiplier for E-Cond model /5.36027425/

UMItEHI Uncertainty multiplier (= CI or $C B$ ) assigned at runtime

SDDMBHL std dev (sqrt variance) of DMB model

$10.316670 /$

CIDMBHL

958 confidence interval multiplier for DMB model /1.660391/

B.1 


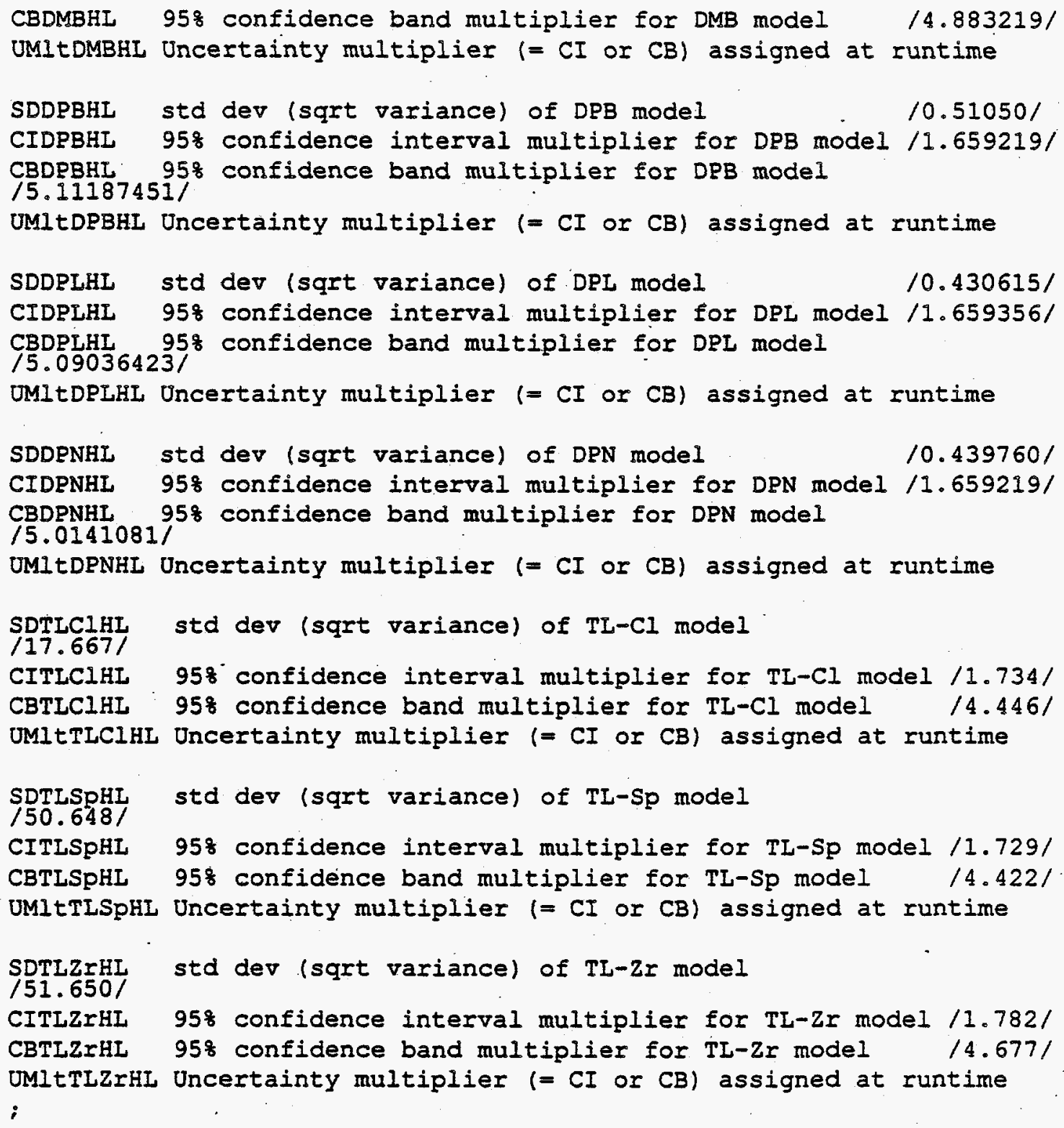


TABLE CovarVHI (EXTDHLI, EXTDHIJ) Eulcher model

$\begin{array}{lrrrr} & \text { SiO2 } & \text { B2O3 } & \text { Na2O } & \text { Li2O } \\ \text { SiO2 } & 1.45 & -1.77 & -1.11 & -3.19 \\ \text { B203 } & -1.77 & 5.44 & 1.33 & 3.99 \\ \text { Na2O } & -1.11 & 1.33 & 6.27 & 1.21 \\ \text { Li20 } & -3.19 & 3.99 & 1.21 & 28.44 \\ \text { CaO } & -0.95 & -0.51 & -1.17 & 0.67 \\ \text { MgO } & -1.34 & 0.69 & -0.4 & 2.46 \\ \text { Fe203 } & -1.71 & 0.46 & 0.6 & 1.99 \\ \text { Al203 } & -0.27 & -0.87 & -2.99 & -3.53 \\ \text { ZrO2 } & -0.74 & 0.35 & -1.32 & -5.07 \\ \text { Other } & -1.23 & 0.57 & -1.64 & -1.03 \\ \text { SiO2TS } & -1623.82 & 1940.71 & 1181.677 & 3504.86 \\ \text { B203TS } & 1953.2 & -6059.14 & -1532.758 & -4321.55 \\ \text { Na2OTS } & 1251.12 & -1470.25 & -6904.259 & -1178.44 \\ \text { Li2OTS } & 3581.96 & -4333.24 & -968.43 & -31806.81 \\ \text { CaOTS } & 1072.31 & 699.29 & 1441.571 & -600.24 \\ \text { MgOTS } & 1516 & -666.54 & 482.642 & -2419.01 \\ \text { Fe203TS } & 1874.37 & -474.39 & -689.163 & -2193.94 \\ \text { Al2O3TS } & 278.55 & 979.48 & 3370.684 & 3755.13 \\ \text { ZrO2TS } & 794.34 & -264.74 & 1475.635 & 5806.68 \\ \text { OtherTS } & 1336.84 & -592.46 & 1950.806 & 1227.74 \\ \text { SiO2BXTSQ } & 37.02 & -45.44 & -28.23 & -80.09 \\ \text { B203BXTSQ } & -45.35 & 136.93 & 33.97 & 102.06 \\ \text { Na2OBXTSQ } & -29.12 & 34.97 & 162.63 & 30.36 \\ \text { Li2OBXTSQ } & -81.52 & 106.36 & 27.62 & 734.16 \\ \text { CaOBXTSQ } & -23.71 & -15.99 & -32.26 & 7.12 \\ \text { MgOBXTSQ } & -34.47 & 14.5 & -9.69 & 55.47 \\ \text { Fe203BXTSQ } & -43.01 & 10.75 & 16.19 & 50.06 \\ \text { Al203BXTSQ } & -5.63 & -21.69 & -77.87 & -92.96 \\ \text { ZrO2BXTSQ } & -16.89 & 5.96 & -34.61 & -139.08 \\ \text { OtherBXTSQ } & -30.26 & 14.44 & -41.22 & -27.75 \\ & & & & \end{array}$

Covar matrix for viscosity for

Covar matri

$$
\mathrm{B} 203
$$

Cix for $v i s c o s i t y$ for




\begin{tabular}{lrrrr} 
& ZrO2 & Other & \multicolumn{1}{c}{ SiO2TS } & \multicolumn{1}{c}{ B2O3TS } \\
SiO2 & & & & \\
B2O3 & 0.74 & -1.23 & -1623.82 & 1953.2 \\
Na2O & 0.35 & 0.57 & 1940.71 & -6059.14 \\
Li20 & -1.32 & -1.64 & 1181.677 & -1532.758 \\
CaO & -5.07 & -1.03 & 3504.86 & -4321.55 \\
MgO & 0.9 & 1.8 & 1019.95 & 689.39 \\
Ee2O3 & 1 & 0.49 & 1481.09 & -717.47 \\
Al203 & 1.42 & 2.09 & 1884.94 & -480.46 \\
ZrO2 & 3.78 & 2.23 & 293.47 & 990.36 \\
Other & 12.09 & 1.24 & 793.12 & -321.07 \\
SiO2TS & 1.24 & 11.91 & 1324.03 & 614.99 \\
B2O3TS & 793.12 & 1324.03 & 1870487.98 & -2174808.43 \\
Na2OTS & -321.07 & 614.99 & -2174808.43 & 6911647.08 \\
Li2OTS & 1457.88 & 1901.55 & -1388107.47 & 1722995.12 \\
CaOTS & 5798.06 & 1280.68 & -4071108.37 & 4741411.64 \\
MgOTS & -986.33 & -1936 & -1209626.91 & -940971.25 \\
Fe2O3TS & -1199.84 & -372.21 & -1748998.88 & 6837.58 .94 \\
Al2O3TS & -1648.22 & -2341.06 & -2118947.65 & 510127.5 \\
ZrO2TS & -4186.48 & -2509.76 & -325935.74 & -1167359.69 \\
OtherTS & -13426.36 & -1295.28 & -899635.65 & 182513.69 \\
SiO2BXTSQ & -1307.52 & -13322.3 & -1492336.93 & 617096.84 \\
B2O3BXTSQ & -17.33 & -30.39 & -42964.92 & 51327.42 \\
Na2OBXTSQ & 6.45 & 13.75 & 51167.27 & -157858.67 \\
Li2OBXTSQ & -34.7 & -40.85 & 32294.28 & -41286.95 \\
CaOBXTSQ & -136.6 & -26.78 & 92896.34 & -117217.92 \\
MgOBXTSQ & 23.33 & 47.92 & 26659.23 & 21781.69 \\
Fe203BXTSQ & 26.44 & 13.38 & 39980.28 & -14841.29 \\
Al203BXTSQ & 36.45 & 49.53 & 49308.93 & -11629.71 \\
ZrO2BXTSQ & 97.46 & 53.88 & 6797.28 & 26412.27 \\
OtherBXTSQ & 309.22 & 26.9 & 19467.74 & -3795.57 \\
& 26.72 & 304.11 & 34100.16 & -15015.37 \\
& & & &
\end{tabular}

B. 5 


\begin{tabular}{|c|c|c|c|c|}
\hline+ & Na2OTS & Li20TS & CaOts & MgOTs \\
\hline SiO2 & 1251.12 & 3581.96 & 1072.31 & 1516 \\
\hline $\mathrm{B} 203$ & -1470.25 & -4333.24 & 699.29 & -666.54 \\
\hline $\mathrm{Na} 2 \mathrm{O}$ & -6904.259 & -968.43 & 1441.571 & 482.642 \\
\hline Li20 & -1178.44 & -31806.81 & -600.24 & -2419.01 \\
\hline $\mathrm{CaO}$ & 1316.77 & -648.9 & -22092.26 & -6190.94 \\
\hline Mgo & 461.52 & -2630.74 & -6020.58 & -19211.27 \\
\hline $\mathrm{Fe} 2 \mathrm{O} 3$ & -617.24 & -2071.51 & -1055.19 & -713.01 \\
\hline A1203 & 3347.69 & 3730.45 & 920.15 & -575.42 \\
\hline $\mathrm{zrO2}$ & .1457 .88 & 5798.06 & -986.33 & -1199.84 \\
\hline other & 1901.55 & 1280.68 & -1936 & -372.21 \\
\hline Si02TS & -1388107.47 & -4071108.37 & -1209626.91 & 1748998.88 \\
\hline B203TS & 1722995.12 & 4741411.64 & -940971.25 & 63758.94 \\
\hline Na2OTS & 7790388.71 & 1041302.59 & -1570877.07 & -521394.29 \\
\hline Li20TS & 1041302.59 & 36672881.49 & 749332.21 & 2653888.85 \\
\hline Caots & -1570877.07 & 749332.21 & 25095263.86 & 7269517.5 \\
\hline MgOTS & -521394.29 & 2653888.85 & 7269517.5 & 22309878.08 \\
\hline Fe203Ts & 691677.59 & 2216637.63 & . $\quad 885876.72$ & 859413.23 \\
\hline A1203TS & -3852812.44 & -4105376.92 & -1283815.55 & 612756.37 \\
\hline ZrO2TS & -1645121.84 & -6742289.24 & 1168402.71 & 1470012.6 \\
\hline OtherTs & -2283900.18 & -1561222.23 & 2227184.63 & 236061.19 \\
\hline SIO2BXTSQ & 33225.89 & 93419.68 & 27070.84 & 41289.25 \\
\hline B203BXTSQ & -38991.58 & -113766.42 & 22649.44 & -13225.27 \\
\hline Na2OBXTSQ & -184403.04 & -26731.62 & 36542.24 & 11132.09 \\
\hline Li2OBXTSQ & -29387.2 & -852861.31 & -6440.79 & -62242.1 \\
\hline CaOBXTSQ & 35800.4 & -8811.1 & -580349.24 & -163290.15 \\
\hline MgOBXTSQ & 11070.14 & -59974.41 & -159628.25 & -518474.1 \\
\hline Ee203BXTSQ & -16433.39 & -50806.84 & -26620.04 & -24041.44 \\
\hline A1203BXTSQ & 89785.44 & 103196.32 & 27159.95 & -19324.8 \\
\hline ZrO2BXTSQ & 38988.31 & 162696.87 & -26551.46 & -34711.93 \\
\hline OtherBXTSQ & 49026.19 & 36824.08 & -53676.12 & -10773.44 \\
\hline
\end{tabular}




\begin{tabular}{|c|c|c|c|c|}
\hline+ & Fe203Ts & AI203TS & Zr02TS & OtherTs \\
\hline $\mathrm{SiO} 2$ & 1874.37 & 278.55 & 794.34 & 1336.84 \\
\hline $\mathrm{B} 203$ & -474.39 & 979.48 & -264.74 & -592.46 \\
\hline $\mathrm{Na} 2 \mathrm{O}$ & -689.163 & 3370.684 & 1475.635 & 1950.806 \\
\hline $\operatorname{Li20}$ & -2193.94 & 3755.13 & 5806.68 & 1227.74 \\
\hline $\mathrm{CaO}$ & -1029.44 & 977.41 & -1033.44 & -2033.51 \\
\hline MgO & -663.22 & -632.92 & -1138.93 & -381.11 \\
\hline $\mathrm{Fe} 203$ & -8656.58 & -2065.53 & -1655.27 & -2319.48 \\
\hline AI203 & -2026.5 & -8229.95 & -4168.48 & -2538.29 \\
\hline 2502 & -1648.22 & -4186.48 & -13426.36 & -1307.52 \\
\hline Other & -2341.06 & -2509.76 & -1295.28 & -13322.3 \\
\hline SiO2TS & -2118947.65 & -325935.74 & -899635.65 & -1492336.93 \\
\hline B203TS & 510127.5 & -1167359.69 & 182513.69 & 617096.84 \\
\hline Na2OTS & 691677.59 & -3852812.44 & -1645121.84 & -2283900.13 \\
\hline Li20TS & 2216637.63 & -4105376.92 & -6742289.24 & -1561222.2 \\
\hline CaOTs & 885876.72 & -1283815.55 & 1168402.71 & 2227184.6 \\
\hline Mgots & 859413.23 & 612756.37 & 14.70012 .6 & 236061.19 \\
\hline Ee203Ts & 10149083.9 & 2411446.29 & 2011910.12 & 2649988.1 \\
\hline Al203TS & 2411446.29 & 9481972.9 & 4767106.17 & 2957260.6 \\
\hline Zro2TS & 2011910.12 & 4767106.17 & 15321751.33 & 1440152.9 \\
\hline OtherTs & 2649988.14 & 2957260.69 & 1440152.97 & 15383114.9 \\
\hline SiO2BXTSQ & 49439.22 & 7099.13 & 19976.02 & 34650.96 \\
\hline B2O3BXTSQ & -11805.12 & 26602.73 & -3027.62 & -13763.3 \\
\hline Na2OBXTSQ & -18573.07 & 90478.07 & 39658.12 & 49832.71 \\
\hline Li2OBXTSQ & -53145.48 & 102443.7 & 160340.07 & 34072.41 \\
\hline CaOBXTSQ & -25885.54 & 27953.9 & -27669.97 & -55325.37 \\
\hline MgOBXTSQ & -24628.35 & -18751.15 & -33334.75 & -10527.49 \\
\hline Fe203BXTSQ & -232468.32 & -55002.63 & -45702.66 & -56713.15 \\
\hline Al203BXTSO & -53845.9 & -223612.39 & -112462.34 & -64708.02 \\
\hline ZrO2BXTSQ & -44892.45 & -112013.32 & -356977.2 & -30563.03 \\
\hline OtherBXTSQ & -58149.36 & -64063.98 & -29990.83 & -355966.18 \\
\hline
\end{tabular}

B.7 . 


\begin{tabular}{|c|c|c|c|c|}
\hline+ & SiO2BXTSQ & B203BXTSQ & Na2OBXTSQ & Li2OBXTSQ \\
\hline $\mathrm{SiO} 2$ & 37.02 & -45.35 & -29.12 & -81.52 \\
\hline B203 & -45.44 & 136.93 & 34.97 & 106.36 \\
\hline $\mathrm{Na} 2 \mathrm{O}$ & -28.23 & 33.97 & 162.63 & 27.62 \\
\hline Li20 & -80.09 & 102.06 & 30.36 & 734.16 \\
\hline $\mathrm{CaO}$ & -22.98 & -17.28 & -29.5 & 6.82 \\
\hline Mgo & -34.82 & 13.83 & -9.13 & 62.68 \\
\hline $\mathrm{Fe} 2 \mathrm{O} 3$ & -43.37 & 11.24 & 16.4 & 49.12 \\
\hline A1203 & -6.12 & -22.01 & -78.18 & -92.27 \\
\hline 2ro2 & -17.33 & 6.45 & -34.7 & -136.6 \\
\hline Other & -30.39 & 13.75 & -40.85 & -26.78 \\
\hline SiO2TS & -42964.92 & 51167.27 & 32294.28 & 92896.34 \\
\hline B203TS & 51327.42 & -157858.67 & -41286.95 & -117217.92 \\
\hline Na2OTS & 33225.89 & -38991.58 & -184403.04 & -29387.2 \\
\hline Li20TS & 93419.68 & -113766.42 & -26731.62 & -852861.31 \\
\hline CaOTs & 27070.84 & 22649.44 & 36542.24 & -6440.79 \\
\hline Mgots & 41289.25 & -13225.27 & 11132.09 & -62242.1 \\
\hline Fe203Ts & 49439.22 & -11805.12 & -18573.07 & -53145.48 \\
\hline Al203TS & 7099.13 & 26602.73 & 90478.07 & 102443.7 \\
\hline Zro2TS & 19976.02 & -3027.62 & 39658.12 & 160340.07 \\
\hline OtherTs & 34650.96 & -13763.3 & 49832.71 & 34072.41 \\
\hline SIO2BXTSQ & 1005.1 & -1215.99 & -790.49 & -2176.16 \\
\hline B203EXTSQ & -1215.99 & 3671.299 & 37.09 & 2800.1 \\
\hline Na2OBXTSQ & -790.49 & 937.09 & 4433.55 & 786.69 \\
\hline Li2OBXTSQ & -2176.16 & 2800.1 & 786.69 & 20228.3 \\
\hline CaOBXTSQ & -610.09 & -543.73 & -822.37 & -4.22 \\
\hline MgOBXTSQ & -967.02 & 275.13 & -222.64 & 1451.27 \\
\hline Fe203BXTSQ & -1167.51 & 275.21 & 430.64 & 1201.38 \\
\hline A1203BXTSQ & -157.43 & -622.6 & -2131.18 & -2592.13 \\
\hline ZrO2BXTSQ & -445.95 & 47.49 & -948.37 & -3894.65 \\
\hline OtherBXTSQ & -810.17 & 326.5 & -1071.82 & -819.03 \\
\hline
\end{tabular}

B.8 


\begin{tabular}{|c|c|c|c|c|}
\hline $26^{\circ}$ DET & $65^{\circ} 09 Z I$ & $S .6 S \varepsilon$ & 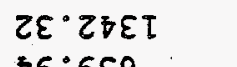 & $\begin{array}{r}\text { OSIXEIәY70 } \\
\text { OSIXgZOxZ }\end{array}$ \\
\hline $26^{\circ} \angle 692$ & $6 E^{\circ} T S O T$ & $6 Z \cdot \tau Z 8$ & $66^{\circ} 6 \varepsilon 9$ & OSLXAZOxZ \\
\hline$\angle L^{\circ} \tau L E S$ & $\varepsilon 6^{\circ}: Z L Z T$ & $B L \cdot \varepsilon 95$ & $\varepsilon \sigma^{\circ} 86 S_{-}$ & OSIXgEOZTH \\
\hline$\varepsilon \sigma^{\circ} Z L Z T$ & $\angle 0^{\circ} 206 S$ & $6 L \cdot 799$ & $S L \cdot E T L$ & OSIXgEOZə马 \\
\hline$D L^{\circ} \varepsilon 9 S$ & $L^{\circ} \nabla 99^{\circ}$ & $\varepsilon \sigma \cdot \nabla I E Z I$. & S2* โ99E & OSIXgO6W \\
\hline$\varepsilon \sigma^{\circ} 865-$ & $S L^{\circ} \varepsilon I L$ & $s 2 \cdot \tau 99 \varepsilon$ & $9^{\circ}$ SI9E & OSIXgOED \\
\hline$\varepsilon I \cdot 26 \subseteq Z-$ & $8 \varepsilon^{\circ} \mathrm{TOZ}$ & $\angle Z \cdot I S D T$ & $22 \cdot 6-$ & OSIXgOZTI \\
\hline $8 I^{\circ}$ IEIZ- & $\nabla 9^{\circ} \mathrm{OED}$ & $69 \cdot 22 z-$ & LE* ZZ৪- & OSIX8OZEN \\
\hline $99^{\circ} 229-$ & $I Z \cdot S L Z$ & $E I \cdot S L Z$ & $\varepsilon L^{\circ} \varepsilon S^{-}$ & OSIXgEOZg \\
\hline$\varepsilon \nabla^{\cdot} \angle S T-$ & IS. $\angle 9 I I-$ & $20 \cdot \angle 96-$ & $60^{\circ}$ ot9- & OSIXaZOTS \\
\hline $20^{\circ} 80 \angle 09-$ & SI'EIL9S- & $60^{\circ} \angle 250 I-$ & LE'SZESS- & SปมәЧ70 \\
\hline 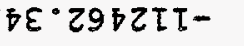 & $99^{\circ} 20 \angle 58-$ & SL・ •EEEE- & $\angle 6^{\circ} 699 \angle Z=$ & SIZOIZ \\
\hline $6 \varepsilon^{\circ}$ 乙โ9ย乙乙- & 89.200SS- & $S T \cdot \tau S L 8 T-$ & $6^{\circ} \varepsilon \subseteq 6 L Z$ & SIEOZTV \\
\hline 65ด8ES- & 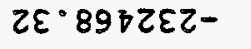 & $S E \cdot 8 Z 9 \mathrm{DZ}-$ & $5 \cdot 5885 Z-$ & SIEOZə马 \\
\hline 8. ธ2ร6โ- & $56^{\circ}$ โ6OBZ- & $I^{\circ} T \angle B 8 T S-$ & SI.06ZE9 T- & SปO6W \\
\hline $56^{\circ} 6 S I L Z$ & $10^{\circ} 02992-$ & $5 Z \cdot 8 Z 965 I-$ & จ2 6ธE085- & SLOEJ \\
\hline ZE.96TEOT & $88^{\circ} 90805-$ & $I 0^{\circ} \quad \angle 66 S^{-}$ & I*IT88- & SLOZTI \\
\hline 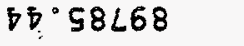 & 6ย๋ ยะซ9 I- & $B T^{\circ}$ OLOTI & $\checkmark .0085 \varepsilon$ & SIOZEN \\
\hline$\angle て \cdot Z \tau+9 Z$ & IL'629Tโ- & $62 \cdot \tau b 85 \tau-$ & $69^{\circ} \tau 8<I Z$ & SIEOZg \\
\hline $82^{\circ} \angle 6 \angle 9$ & $\varepsilon \sigma^{\circ} 80 \varepsilon 65$ & $82 \cdot 0866 \varepsilon$ & $\varepsilon z \cdot 6 \$ 99 Z$ & SIZOTS \\
\hline $88^{\circ} \varepsilon S$ & $E S^{\circ} 60$. & $8 \varepsilon^{\cdot} \varepsilon \tau$ & $26^{\circ} \angle 5$ & хәน70 \\
\hline $90^{\circ} 16$ & $50^{\circ} 9 \varepsilon$ & $\$ 0^{\circ} 92$ & $\varepsilon \varepsilon^{\circ} \varepsilon \mathcal{Z}$ & $20=\mathrm{z}$ \\
\hline $88^{\circ} \tau 6 I$ & $\angle T \cdot S B$ & $8^{\circ} 9 I$ & $\tau 9^{\circ} 6 \tau-$ & EOZTH \\
\hline $26^{\circ} \circ$ & $80^{\circ} 56 \mathrm{I}$ & $20^{\circ} 02$ & $82^{\circ} 62$ & EOzas \\
\hline $56^{\circ} 8 I$ & $\angle E^{\circ} 8 T$ & $56^{\circ} 075$ & $\varepsilon 0^{\circ} \nabla \varepsilon \tau$ & ODW \\
\hline $28^{\circ} 6 I-$ & $I \varepsilon^{\circ} 62$ & $I T^{\circ} S E \tau$ & $60^{\circ} \mathrm{LOS}$ & oes \\
\hline $96^{\circ} 26^{-}$ & $90^{\circ}$ OS & $\angle 5^{\circ} \mathrm{gS}$ & $Z I^{\circ} L$ & $02 \div 7$ \\
\hline$\angle 8^{\circ} \mathrm{LL}=$ & $6 I^{\circ} 9 T$ & $69^{\circ} 6-$ & $9 Z^{\circ} Z \varepsilon-$ & OZEN \\
\hline $69^{\circ}$ โZ- & $S L^{\circ} O T$ & $S^{*}$ 酐 & $66^{\circ} \mathrm{SI-}$ & EOZ\& \\
\hline$\varepsilon q \cdot g-$ & $\tau 0^{\circ} \varepsilon \nabla-$ & $\angle D^{\circ} \cdot E-$ & $I L \cdot \varepsilon Z-$ & $20 \div S$ \\
\hline OSIX\&EOZTH & 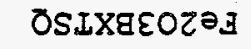 & రSLXgOБพ & OSIXEOES & + \\
\hline
\end{tabular}




\begin{tabular}{|c|c|c|}
\hline+ & ZrO2BXISQ & OtherBXTSQ \\
\hline SiO2 & -16.89 & -30.26 \\
\hline $\mathrm{B} 203$ & 5.96 & 14.44 \\
\hline $\mathrm{Na} 2 \mathrm{O}$ & -34.61 & -41.22 \\
\hline Li20 & -139.08 & -27.75 \\
\hline $\mathrm{CaO}$ & 23.53 & 48.93 \\
\hline Mgo & 26.22 & 13.91 \\
\hline Fe203 & 35.91 & 50.27 \\
\hline Al203 & 96.58 & 53.93 \\
\hline Zro2 & 309.22 & 26.72 \\
\hline Other & 26.9 & 304.11 \\
\hline Sio2TS & 19467.74 & 34100.16 \\
\hline B203TS & -3795.57 & -15015.37 \\
\hline Na2OTS & 38988.31 & 49026.19 \\
\hline Ii2OTS & 162696.87 & 36824.08 \\
\hline CaOTs & -26551.46 & -53676.12 \\
\hline Mgots & -34711.93 & -10773.44 \\
\hline Fe203Ts & -44892.45 & -58149.36 \\
\hline A1203Ts & -112013.32 & .64063 .98 \\
\hline ZrO2TS & -356977.2 & -29990.8 \\
\hline otherTs & -30563.03 & -355966.1 \\
\hline SiO2BXTSQ & -445.95 & -810.17 \\
\hline B203BXTSQ & 47.49 & 326 \\
\hline Na2OBXTSQ & -948.37 & -1071.82 \\
\hline Li2OBXTSQ & -3894.65 & -819.03 \\
\hline CaOBXTSQ & 639.94 & 1342.32 \\
\hline MgOBXTSO & 821.29 & 359. \\
\hline Ee203BXTSQ & 1051.39 & 1260.59 \\
\hline Al203BXTSQ & 2697.92 & 1434.92 \\
\hline ZrO2BXTSQ & 8461.59 & 654.17 \\
\hline OtherBXTSQ & 654.17 & 8411.84 \\
\hline
\end{tabular}

B. 10 
TABLE XtXIEHL (EXTDHLI, EXTDHLJ)
foI Arrhenius model

SIO2

$\begin{array}{lr}\text { SIO2 } & 28.092975637 \\ \text { B2O3 } & -20.45039003 \\ \text { NA2O } & -29.84457112 \\ \text { LI2O } & -42.81692192 \\ \text { CAO } & -4.986749218 \\ \text { MGO } & -20.02243047 \\ \text { FE2O3 } & -35.97951226 \\ \text { AL2O3 } & -23.18396659 \\ \text { ZRO2 } & -23.51812887 \\ \text { OTHER } & -40.39062298 \\ \text { SIO2T } & -37860.79547 \\ \text { B2O3T } & 27583.03275 \\ \text { NA2OT } & 40502.851538 \\ \text { LI2OT } & 57885.236937 \\ \text { CAOT } & 5995.1796458 \\ \text { MGOT } & 26451.291556 \\ \text { FE2O3T } & 48126.772416 \\ \text { AL2O3T } & 31121.301095 \\ \text { ZRO2T } & 31197.940079 \\ \text { OTHERT } & 54491.86345\end{array}$

$+$

$\begin{array}{lr}\text { SIO2 } & -4.986749218 \\ \text { B2O3 } & -34.25345149 \\ \text { NA2O } & -18.04318818 \\ \text { LI2O } & -26.54016321 \\ \text { CAO } & 317.65526608 \\ \text { MGO } & 97.783369763 \\ \text { FE2O3 } & -43.54684485 \\ \text { AL2O3 } & 13.508844253 \\ \text { ZRO2 } & 2.4829211437 \\ \text { OTHER } & 26.56790329 \\ \text { SIO2T } & 5773.7526739 \\ \text { B2O3T } & 47439.851166 \\ \text { NA2OT } & 24995.233168 \\ \text { LI2OT } & 40326.696617 \\ \text { CAOT } & -427333.283 \\ \text { MGOT } & -131257.6583 \\ \text { EE2O3T } & 61444.706721 \\ \text { AL2O3T } & -18877.40706 \\ \text { ZRO2T } & -4998.637803 \\ \text { OTHERT } & -35557.0191\end{array}$

$\mathrm{B2O3}$

$-20.45039003$

98.201107298

13.388919134

$-0.731121548$

$-34.25345149$

$-11.8316473$

1.1701434315

$-17.45734375$

2. 3132710911

6.6252635466

27503.05649

$-132113.1317$

$-18458.48681$

1149.5861836

47173.254651

16724.344163

$-424.953368$

23724.703355

$-2829.739527$

$-9859.427878$
(XtX)-1 matrix for e-conductivity

NA2O

LI20

$-29.84457112$

13.388919134

136.58485143

55.311274387

$-18.04318818$

$-1.545640131$

2.1687742523

$-38.07137382$

$-29.00100872$

0.4230065669

40617.778907

$-18715.1158$

$-184878.6846$

$-76872.23545$

24530.71252

1972.4283066

$-2390.797548$

51750.813024

40043.03838

$-418.326177$

FE203

AL2O3

$-35.97951226$

$-23.18396659$

$-17.45734375$

$-38.07137382$

$-70.58656158$

13.508844253

18.674264402

90.186896086

174.82681363

103.5199129

44.50542219

31053.349132

23908.189628

51660.919489

96720.003927

$-18392.31355$

$-24371.74392$

$-122707.9603$

$-235961.6059$

$-139727.7733$

$-60091.03931$

B.11 
$+$

$\begin{array}{lr}\text { SIO2 } & -23.51812887 \\ \text { B2O3 } & 2.3132710911 \\ \text { NA2O } & -29.00100872 \\ \text { LI2O } & -66.18703145 \\ \text { CAO } & 2.4829211437 \\ \text { MGO } & -12.79878641 \\ \text { EE2O3 } & 64.863442981 \\ \text { AI2O3 } & 103.5199129 \\ \text { ZRO2 } & 255.16510207 \\ \text { OTHER } & 19.997363614 \\ \text { SIO2T } & 31269.275856 \\ \text { B2O3T } & -2785.293069 \\ \text { NA2OT } & 39867.937675 \\ \text { LI2OT } & 91868.365386 \\ \text { CAOT } & -4760.023603 \\ \text { MGOT } & 17181.878318 \\ \text { EE2O3T } & -88933.1939 \\ \text { AI2O3T } & -139666.6431 \\ \text { ZRO2T } & -344912.5756 \\ \text { OTHERT } & -24699.04842 \\ & -246\end{array}$

$+$

SIO2

B203

NA2O

LI20

CAO

MGO

EE203

AL203

ZRO2

OTHER

SIO2T

B203T

NA2OT

LI2OT

CAOT

MGOT

EE203T

AL203T

ZRO2T

OTHERT

40502.851538

$-18458.48681$

$-184878.6846$

$-76381.23859$

24995.233168

2027.948815

$-2070.153742$

51660.919489

39867.937675

$-416.6076008$

$-55566186.41$

26063878.806

252022294.84

107244444.88

$-34000826.46$

$-2556276.204$

2114285.8744

$-70845615.38$

$-55476684.1$

312521.81771
OTHER

$-40.39062298$

6.6252635466

0.4230065669

$-10.38519723$

26.56790329

9.9874667161

54.273151565

44.50542219

19.997363614

313.59463685

54347.145394

$-9621.912498$

$-416.6076008$

14346.412016

$-34704.31884$

$-11229.47761$

$-72668.95107$

$-60196.21059$

$-24655.63452$

$-424017.7718$

\section{II2OT}

57885.236937

1149.5861836

$-76872.23545$

$-719254.6829$

40326.696617

$-13222.15303$

42907.721279

96720.003927

91868.365386

14346.412016

$-79315954.33$

$-303172.3355$

107244444.88

984263828.86

$-57859271.82$

14068316.934

$-61405019.61$

$-133806529.1$

$-129480357.9$

$-19693647.14$
SIO2T

B203T

$\begin{array}{rr}-37860.79547 & 27583.03275 \\ 27503.05649 & -132113.1317 \\ 40617.778907 & -18715.1158 \\ 57973.781349 & 523.09514684 \\ 5773.7526739 & 47439.851166 \\ 26529.575558 & 16600.677992 \\ 48016.429502 & -329.498 .8369 \\ 31053.349132 & 23908.189628 \\ 31269.275856 & -2785.293069 \\ 54347.145394 & -9621.912498 \\ 51445874.836 & -37457678 \\ -37457678 & 179149283.03 \\ -55566186.41 & 26063878.806 \\ -79315954.33 & -303172.3355 \\ -7019489.964 & -65460681.27 \\ -35395029.29 & -23510977.71 \\ -64735263.39 & -994534.5394 \\ -41865014.96 & -32867774.02 \\ -41691554.7 & 3170082.758 \\ -73761132.2 & 14190099.93\end{array}$

CAOT

MGOT

5995.1796458

47173.254651

24530.71252

38722.584613

$-427333.283$

$-131540.4662$

61382.639394

$-18392.31355$

$-4760.023603$

$-34704.31884$

$-7019489.964$

$-65460681.27$

$-34000826.46$

$-57859271.82$

579397752.47

177846534.47

$-86775503.2$

25529310.349

8602902.44

46556005.505
26451.291556

16724.344163

1972.4283066

$-12734.89674$

$-131257.6583$

$-521997.1338$

7960.9014822

$-24371.74392$

17181.878318

$-11229.47761$

$-35395029.29$

$-23510977.71$

$-2556276.204$

14068316.934

177846534.47

707510770.6

$-8673485.43$

32157352.831

$-22973931.8$

12644634.017

B. 12 


\begin{tabular}{|c|c|c|c|c|}
\hline+ & FE203T & AL203T & ZRO2T & OTHERT \\
\hline SIO2 & 48126.772416 & 31121.301095 & 31197.940079 & 54491.86345 \\
\hline 203 & -424.953368 & 23724.703355 & -2829.739527 & -9859.427878 \\
\hline IA2O & -2390.797548 & 51750.813024 & 40043.03838 & -418.326177 \\
\hline$I 20$ & 42050.139166 & 96622.375673 & 92435.255467 & 13881.736414 \\
\hline AO & 61444.706721 & -18877.40706 & -4998.637803 & -35557.0191 \\
\hline IGO & 7965.1251207 & -24450.08528 & 17305.990575 & -11591.57169 \\
\hline E203 & -268773.571 & -123079.6132 & -89062.0384 & -73096.78018 \\
\hline L2O3 & -122707.9603 & -235961.6059 & -139727.7733 & -60091.03931 \\
\hline RO2 & -88933.1939 & -139666.6431 & -344912.5756 & -24699.04 \\
\hline THER & -72668.95107 & -60196.21059 & -24655.63452 & 017.7718 \\
\hline IO2T & -64735263.39 & -41865014 & -41691554.7 & 761132.2 \\
\hline $3203 T$ & -994534.5394 & -3286777 & 3170082.758 & .93 \\
\hline IA2OT & 2114285.8744 & -70845615 & -55476684.1 & 312521.81 \\
\hline I $20 T$ & -61405019.61 & -1338065 & -129480357.9 & 3647.14 \\
\hline AOT & -86775503.2 & 529310. & 8602902.44 & 6005.505 \\
\hline MGOT & -8673485.43 & 32157352.831 & -22973931.8 & 4634.017 \\
\hline EE203T & 366510680.24 & 168475443.08 & 12277975.3 .52 & 98302517.384 \\
\hline AL203T & & & 189945701.25 & 81958155.025 \\
\hline ZRO2T & 122779753.52 & 189945701.25 & 469761449.43 & 30513863.347 \\
\hline OTHERT & 98302517.384 & 81958155.025 & 30513863.347 & 577571620.37 \\
\hline
\end{tabular}

B. 13 


$\begin{array}{lrrrr}+ & \text { FE2O3T } & \text {.AL2O3T } & \text { ZRO2T } & \text { OTHERT } \\ \text { SIO2 } & 48126.772416 & 31121.301095 & 31197.940079 & 54491.86345 \\ \text { B2O3 } & -424.953368 & 23724.703355 & -2829.739527 & -9859.427878 \\ \text { NA2O } & -2390.797548 & 51750.813024 & 40043.03838 & -418.326177 \\ \text { LI20 } & 42050.139166 & 96622.375673 & 92435.255467 & 13881.736414 \\ \text { CAO } & 61444.706721 & -18877.40706 & -4998.637803 & -35557.0191 \\ \text { MGO } & 7965.1251207 & -24450.08528 & 17305.990575 & -11591.57169 \\ \text { FE203 } & -268773.571 & -123079.6132 & -89062.0384 & -73096.78018 \\ \text { AL2O3 } & -122707.9603 & -235961.6059 & -139727.7733 & -60091.03931 \\ \text { ZRO2 } & -88933.1939 & -139666.6431 & -344912.5756 & -24699.04842 \\ \text { OTHER } & -72668.95107 & -60196.21059 & -24655.63452 & -424017.7718 \\ \text { SIO2T } & -64735263.39 & -41865014.96 & -41691554.7 & -73761132.2 \\ \text { B2O3T } & -994534.5394 & -32867774.02 & 3170082.758 & 14190099.93 \\ \text { NA2OT } & 2114285.8744 & -70845615.38 & -55476684.1 & 312521.81771 \\ \text { LI2OT } & -61405019.61 & -133806529.1 & -129480357.9 & -19693647.14 \\ \text { CAOT } & -86775503.2 & 25529310.349 & 8602902.44 & 46556005.505 \\ \text { MGOT } & -8673485.43 & 32157352.831 & -22973931.8 & 12644634.017 \\ \text { FE2O3T } & 366510680.24 & 168475443.08 & 122779753.52 & 98302517.384 \\ \text { AL2O3T } & 168475443.08 & 320836573.79 & 189945701.25 & 81958155.025 \\ \text { ZRO2T } & 122779753.52 & 189945701.25 & 469761449.43 & 30513863.347 \\ \text { OTHERT } & 98302517.384 & 81958155.025 & 30513863.347 & 577571620.37 \\ \text {; } & & & & \end{array}$

B. 13 
TABLE XtXIDMBHL (EXTDHLI, EXTDHLJ)
(MCC-borOn) fOr nonlinear model \#2

\begin{tabular}{|c|c|c|c|c|}
\hline & $\mathrm{SiO} 2$ & B203 & $\mathrm{Na} 2 \mathrm{O}$ & $\mathrm{Li20}$ \\
\hline iO2 & 2.314064663 & -2.567515849 & -1.771611935 & -2.561434172 \\
\hline 3203 & -2.567515849 & 10.71497223 & 1.473221063 & 2.339172608 \\
\hline $\mathrm{Na2O}$ & -1.771611935 & 1.473221063 & 6.219445806 & 2.44182813 \\
\hline Li20 & -2.561434172 & 2.339172608 & 2.44182813 & 20.16526667 \\
\hline $\mathrm{CaO}$ & 26.46779357 & -32.4780005 & -28.08068877 & -19.0218942 \\
\hline Mgo & -4.621367402 & 4.739153063 & 11.70361801 & 0.497095844 \\
\hline Fe203 & -3.077346797 & 1.157586987 & 0.450833189 & 0.487725242 \\
\hline A1203 & -6.8 & 5.639016069 & 0.300902747 & 0.722554656 \\
\hline $\mathrm{ZrO} 2$ & -2.349999326 & -0.400164019 & -0.922679166 & -1.357398579 \\
\hline Other & -2.902207371 & 0.877441567 & 0.867908464 & -0.416554977 \\
\hline$\perp-A \perp$ & 14.3212684 & 26.89477895 & -0.677318881 & 1236891 \\
\hline$-A I$ & 21.03765703 & -99.12010223 & -11.23479144 & -16.30610978 \\
\hline$i-\mathrm{Ca}$ & -47.39513486 & 54.26224737 & 44.79058176 & 23.80475054 \\
\hline $\mathrm{a}-\mathrm{Ca}$ & -49.28761271 & 61.49939443 & 75.81297115 & 103.7089561 \\
\hline $\mathrm{Na}-\mathrm{Mg}$ & 33.82429991 & -29.80865457 & -101.78669964 & 7.99652033 \\
\hline & $\mathrm{CaO}$ & Mgo & $\mathrm{Ee} 203$ & Al203 \\
\hline iO2 & 26.46 & -4.621367402 & -3.077346797 & -6.878955353 \\
\hline $\mathrm{B} 203$ & -32.4780 & 4.739153063 & 1.157586987 & 9016069 \\
\hline $\mathrm{Na2O}$ & -28.08068877 & 11.70361801 & 0.450833189 & 0.300902747 \\
\hline Li20 & -19.0218942 & 0.497095844 & 0.487725242 & 0.722554656 \\
\hline $\mathrm{CaO}$ & 872.3 & -64.09891273 & -32.88776077 & -76.54009227 \\
\hline MgO & -64.09891273 & 88.58653901 & 1.123643603 & 12.67576193 \\
\hline$F \in 203$ & -32.8 & 1.1236436 & 10.20858926 & 4432011 \\
\hline Al203 & -76.54009227 & 12.67576193 & 10.04432011 & 73.88617604 \\
\hline $\mathrm{ZrO2}$ & -28.02483877 & -1.4641863 & 5.132571595 & 13.11785888 \\
\hline Other & -40.21538439 & 5.154499767 & 4.536849074 & 5.913500941 \\
\hline$A I-A I$ & 197.3003113 & 8.503161686 & -20.90361449 & -287.06573 \\
\hline$B-A I$ & 148.05194 & -116.8313284 & -4.034016994 & -122.2937233 \\
\hline $\mathrm{Si}-\mathrm{Ca}$ & -1382.468593 & 96.2518223 & 65.39292431 & 77.32248522 \\
\hline $\mathrm{Ca}-\mathrm{Ca}$ & -2379.406614 & 236.2378923 & 12.9549973 & 453.5621028 \\
\hline $\mathrm{Na}-\mathrm{Mg}$ & 470.5883961 & -669.8169964 & -17.11029614 & -144.8299367 \\
\hline
\end{tabular}

B. 14 
Other

AI-AI

B-AI

\begin{tabular}{|c|c|c|c|c|}
\hline $\mathrm{SiO} 2$ & -2.349999326 & -2.902207371 & 14.3212684 & 21.03765703 \\
\hline B203 & -0.400164019 & 0.877441567 & 26.89477895 & -99.12010223 \\
\hline $\mathrm{Na} 2 \mathrm{O}$ & -0.922679166 & 0.867908464 & -0.677318881 & -11.23479144 \\
\hline Li20 & -1.357398579 & -0.416554977 & -8.331236891 & -16.30610978 \\
\hline $\mathrm{CaO}$ & -28.02483877 & -40.21538439 & 197.3003113 & 148.05194 \\
\hline $\mathrm{MgO}$ & -1.464186316 & 5.154499767 & 8.503161686 & -116.831328 \\
\hline $\mathrm{Fe} 203$ & 5.132571595 & 4.536849074 & -20.90361449 & -4.03401699 \\
\hline Al203 & 13.11785888 & 5.913500941 & -287.06573 & -122.29372 \\
\hline $\mathrm{ZrO} 2$ & 11.94311208 & 4.274619069 & -42.38187181 & 6.8722821 \\
\hline Other & 4.274619069 & 13.69620004 & -5.117178736 & -2.17575777 \\
\hline$A 1-A 1$ & -42.38187181 & -5.117178736 & 1809.610947 & -334.659328 \\
\hline$B-A 1$ & 6.872282194 & -2.175757773 & -334.6593283 & 1632.79352 \\
\hline $\mathrm{Si}-\mathrm{Ca}$ & 48.94437502 & 74.33336672 & -7.151483437 & -191.019892 \\
\hline $\mathrm{Ca}-\mathrm{Ca}$ & 55.6998415 & 60.43354069 & -2317.265377 & -512.358947 \\
\hline $\mathrm{Na}-\mathrm{Mg}$ & 5.547174186 & -39.61447776 & 130.9912636 & 980.041958 \\
\hline+ & $\mathrm{Si}-\mathrm{Ca}$ & $\mathrm{Ca}-\mathrm{Ca}$ & $\mathrm{Na}-\mathrm{Mg}$ & \\
\hline $\mathrm{SiO} 2$ & -47.39513486 & -49.28761271 & 33.82429991 & \\
\hline B203 & 54.26224737 & 61.49939443 & -29.80865457 & \\
\hline $\mathrm{Na} 2 \mathrm{O}$ & 44.79058176 & 75.81297115 & -101.7866964 & \\
\hline $\operatorname{Li} 20$ & 23.80475054 & 103.7089561 & 7.99652033 & \\
\hline $\mathrm{CaO}$ & -1382.468593 & -2379.406614 & 470.5883961 & \\
\hline Mgo & 96.2518223 & 236.2378 .923 & -669.8169964 & \\
\hline $\mathrm{Fe} 203$ & 65.39292431 & 12.9549973 & -17.11029614 & \\
\hline Al203 & 77.32248522 & 453.5621028 & -144.8299367 & \\
\hline $\mathrm{ZrO} 2$ & 48.94437502 & 55.6998415 & 5.547174186 & \\
\hline Other & 74.33336672 & 60.43354069 & -39.61447776 & \\
\hline$A I-A I$ & -7.151483437 & -2317.265377 & 130.9912636 & \\
\hline$B-A I$ & -191.0198921 & -512.3589475 & 980.0419586 & \\
\hline $\mathrm{Si}-\mathrm{Ca}$ & 2604.289121 & 1612.802646 & -640.5928249 & \\
\hline $\mathrm{Ca}-\mathrm{Ca}$ & 1612.802646 & 19091.96369 & -1813.18914 & \\
\hline $\mathrm{Na}-\mathrm{Mg}$ & -640.5928249 & -1813.18914 & 6102.573843 & \\
\hline
\end{tabular}

B. 15 
TABLE XTXIDPBHL (EXTDHLI, EXTDHLJ) (PCT-boron) for nonlinear model \#2

(XtX) -1 matrix for durability

$\mathrm{SiO2} \quad \mathrm{B} 2 \mathrm{O} \quad \mathrm{Na2O} \quad \mathrm{Li20}$

\begin{tabular}{|c|c|c|c|c|}
\hline io2 & 2.025550884 & -7.843010848 & -1.562174282 & -1.913845956 \\
\hline 203 & -7.843010848 & 127.8551399 & -1.261880635 & -5.180156274 \\
\hline 20 & -1.562174282 & -1.261880635 & 5.94779636 & 1.830160416 \\
\hline 20 & 1.913845956 & -5.180156274 & 1.830160416 & 19.09379344 \\
\hline $\mathrm{aO}$ & -6.59561083 & 21.70992183 & 11.40082643 & -1.82019211 \\
\hline go & 19.25282102 & 30.72195842 & -20.77907722 & -22.80114134 \\
\hline 203 & -1.534072076 & -7.516684861 & 0.931118217 & 1.293958744 \\
\hline 203 & -1.892548876 & -27.58090618 & 0.036920525 & -0.115705094 \\
\hline $\mathrm{rO2}$ & -1.245873556 & -6.253772782 & -0.751966856 & -0.96649532 \\
\hline sher & -1.174535075 & -9.680005944 & 0.8916 & -0.297383019 \\
\hline$|-A|$ & 6.93690327 & & -1.647 & -8.368937137 \\
\hline$-B$ & 26.99830679 & -532.0267433 & & 29.64755549 \\
\hline$-M g$ & -41.75692287 & -50.19434372 & 40.68731289 & 48.06547044 \\
\hline$-\mathrm{Ca}$ & 28.09694493 & -66.87147098 & -93.75751826 & 31.86606391 \\
\hline$-\mathrm{Ca}$ & 27.86959893 & -135.8101192 & -16.07544596 & -0.769622011 \\
\hline$-7 x$ & 8.281956107 & & 28.20141261 & 7.755535044 \\
\hline & & & & \\
\hline & & & & \\
\hline 03 & 21.70992183 & 2195842 & -7.51 & -27.58090618 \\
\hline 20 & 11.40082643 & 907722 & 0.93 & 0.036920525 \\
\hline 20 & -1.82019211 & -22.80114134 & 1.29 & -0.115705094 \\
\hline 0 & 115.1578768 & -67.34134888 & 0.70 & 1.789123177 \\
\hline zO & -67.3 .4134888 & 876.3750037 & -31.12 & -61.26012455 \\
\hline 203 & 0.703049152 & -31.12045298 & 7.86 & 6.477262323 \\
\hline 20 & 1.789123177 & -61.26012455 & 6.477 & 46.28727524 \\
\hline 02 & -0.468398989 & -24.84589195 & 3.573 & 8.319855446 \\
\hline her & 2.993947196 & -32.08430603 & 2.62 & 4.3755287 .1 \\
\hline$-A$ & -3.591889695 & 168.6777909 & -13.67 & -222.4100746 \\
\hline$-B$ & -51.76801936 & -215.99 & 35.12 & 125.5023829 \\
\hline & & -17 & 64.06 & 1.4895207 \\
\hline & -550.21773 & 6505 & $-14 \cdot 71$ & 1.559706673 \\
\hline & -450.69708 & 273.71 & 376 & -24.63415157 \\
\hline & 53.64645037 & -468.6686934 & -30.71135618 & 28.44779876 \\
\hline
\end{tabular}

B.16 


\begin{tabular}{|c|c|c|c|c|}
\hline+ & $\mathrm{Z}=02$ & Other & $A I-A I$ & $B-B$ \\
\hline $\mathrm{SiO} 2$ & -1.245873556 & -1.174535075 & 6.93690327 & 26.99830679 \\
\hline $\mathrm{B} 203$ & -6.253772782 & -9.680005944 & 97.49400521 & -532.0267433 \\
\hline $\mathrm{Na} 2 \mathrm{O}$ & -0.751966856 & 0.891645591 & -1.647320414 & 9.64052991 \\
\hline $\operatorname{Ii20}$ & -0.96649532 & -0.297383019 & -8.368937137 & 29.64755549 \\
\hline $\mathrm{CaO}$ & -0.468398989 & 2.993947196 & -3.591889695 & -51.76801936 \\
\hline $\mathrm{MgO}$ & -24.84589195 & -32.08430603 & 168.6777909 & -215.9954617 \\
\hline $\mathrm{Ee} 203$ & 3.573483554 & 2.627512902 & -13.67189244 & 35.12236785 \\
\hline$A 1203$ & 8.319855446 & 4.37552871 & -222.4100746 & 23829 \\
\hline $\mathrm{ZrO} 2$ & 11.58160779 & 2.633215749 & -19.59367803 & 27.22924089 \\
\hline Other & 2.633215749 & 10.88614124 & -4.940595861 & 43.56515161 \\
\hline$A I-A I$ & -19.59367803 & -4.940595861 & 1264.627734 & -467.5838866 \\
\hline$B-B$ & 27.22924089 & 43.56515161 & -467.5838866 & 2309.115685 \\
\hline Si-Mg & 58.47901838 & 65.1233521 & -316.7844291 & 382.0234168 \\
\hline $\mathrm{Na}-\mathrm{Ca}$ & 14.82039264 & -19.34766795 & -90.94732705 & 230.6880014 \\
\hline $\mathrm{B}-\mathrm{Ca}$ & -6.2211561 & -3.045051218 & 153.7446565 & 242.5974511 \\
\hline $\mathrm{Mg}-\mathrm{Zr}$ & -132.5914074 & 1.330568177 & -258.1160241 & 446.0701382 \\
\hline+ & $S i-M g$ & $\mathrm{Na}-\mathrm{Ca}$ & $\mathrm{B}-\mathrm{Ca}$ & $M g-Z r$ \\
\hline SiO2 & -41.75692287 & 28.09694493 & 27.86959893 & 356107 \\
\hline $\mathrm{B} 203$ & -50.19434372 & -66.87147098 & -135.8101192 & 3066002 \\
\hline $\mathrm{Na} 2 \mathrm{O}$ & 40.68731289 & -93.757518 .26 & -16.07544596 & 28.20141261 \\
\hline $\mathrm{Li20}$ & 48.06547044 & 31.86606391 & -0.769622011 & 5535044 \\
\hline $\mathrm{CaO}$ & 142.3246379 & -550.2177318 & -450.6970826 & 4645037 \\
\hline MgO & -1734.934184 & 335.7556505 & 273.7154942 & -468.6686934 \\
\hline $\mathrm{Ee} 203$ & 64.06431548 & -14.71741661 & 4.464014376 & -30.71135618 \\
\hline Al203 & 121.4895207 & 1.559706673 & -24.63415157 & 28.44779876 \\
\hline ZrO2 & 58.47901838 & 14.82039264 & -6.2211561 & -132.5914074 \\
\hline Other & 65.1233521 & -19.34766795 & -3.045051218 & 1.330568177 \\
\hline$A I-A I$ & -316.7844291 & -90.94732705 & 153.7446565 & -258.1160241 \\
\hline$B-B$ & 382.0234168 & 230.6880014 & 242.5974511 & 446.0701382 \\
\hline Si-Mg & 3504.721854 & -650.9363113 & -573.188233 & 529.2925864 \\
\hline $\mathrm{Na}-\mathrm{Ca}$ & -650.9363113 & 4360.052206 & 957.3737683 & -491.1483645 \\
\hline $\mathrm{B}-\mathrm{Ca}$ & -573.188233 & 957.3737683 & 3249.815669 & -179.3444639 \\
\hline$M g-Z r$ & 529.2925864 & -491.1483645 & -179.3444639 & 7905.832096 \\
\hline
\end{tabular}


TABLE XTXIDPLHL (EXTDHLI, EXTDHLJ) (XtX)-1 matrix for durability (PCT-lithium) for nonlinear model \#2

$\begin{array}{llll}\mathrm{SiO} 2 \mathrm{~B} & \mathrm{Na2O} & \mathrm{Li} 2 \mathrm{O}\end{array}$

\begin{tabular}{|c|c|c|c|c|}
\hline SiO2 & 1.646745679 & -7.583744375 & -1.759170641 & -1.231457367 \\
\hline $\mathrm{B} 203$ & -7.583744375 & 133.0906284 & -3.91693923 & -2.842790557 \\
\hline 20 & 1.759170641 & -3.91693923 & 10.54213579 & -0.632359036 \\
\hline 20 & 1.231457367 & -2.842790557 & -0.632359036 & 19.69153179 \\
\hline $\mathrm{CaO}$ & -4.686874543 & 28.95605768 & 4.878019311 & -0.344798638 \\
\hline Mgo & -2.132533527 & 0.641915723 & 1.679470348 & 2.637449771 \\
\hline Fe203 & -0.852619138 & -11.36297078 & 0.535443944 & -0.607935849 \\
\hline 1203 & -2.649619511 & -46.93281975 & 8.781062158 & -7.103473818 \\
\hline ZrO2 & -0.386923928 & -7.582691747 & -0.826341235 & -1.827387654 \\
\hline Other & -0.340382239 & -8.078948004 & -0.002798843 & -0.999336243 \\
\hline$A I-A I$ & 7.382393515 & 149.6763729 & 0015 & 0.371250263 \\
\hline $3-B$ & 358 & -547.3552778 & 99319496 & 19.69296564 \\
\hline $1 g-A I$ & 20.7777074 & 68.28203034 & -34.34635283 & -28.55514002 \\
\hline$B-C a$ & 19.55015685 & -164.5486119 & 13.41390787 & -6.68513554 \\
\hline $\mathrm{Na}-\mathrm{Ca}$ & 20.05962385 & -99.86496695 & -61.52286717 & 24.10602745 \\
\hline $\mathrm{Na}-\mathrm{Al}$ & 10.15435433 & 59.03205868 & -89.80537694 & 36.5740469 \\
\hline Ee-Al & 0.459332966 & 126.4568466 & 16.91902114 & 29.52946111 \\
\hline , & $\mathrm{CaO}$ & MgO & & \\
\hline iO2 & -4.686874543 & -2.132533527 & -0.8 & -2.64 \\
\hline B203 & 28.95605768 & 0.641915723 & -11.36297078 & -46.93281975 \\
\hline $\mathrm{Na} 2 \mathrm{O}$ & 4.878019311 & 1.679470348 & 0.535443944 & 8.781062158 \\
\hline Li20 & -0.344798638 & 2.637449771 & -0.607935849 & -7.103473818 \\
\hline $\mathrm{SaO}$ & 118.7695968 & 8.618598835 & -5.319001815 & -19.32361359 \\
\hline Mgo & 8.618598835 & 25.57185623 & -0.8987 & 8.65510 .4113 \\
\hline e203 & -5.319 & -0.89874 & 11.340 .31673 & 19.36772926 \\
\hline$\$ 1203$ & -19.32361359 & 8.655104113 & 19.36772926 & 110.6955819 \\
\hline $\mathrm{ZrO} 2$ & -2.54512 & 1.1954 & 2.464264187 & 9.420657356 \\
\hline Other & 1.010206668 & -0.098465756 & 0.67170 & -0.371088445 \\
\hline $\mid 1-A l$ & 35136 & -23.50176981 & -69. & -408.7669945 \\
\hline$B-B$ & -83.47 & -0.212882043 & 153 & 189.9067133 \\
\hline$M g-A l$ & -81.11871194 & -250.3942932 & $\$ 7496195$ & -194.2191505 \\
\hline $\mathrm{B}-\mathrm{Ca}$ & -464.4720217 & -26.28814366 & 25.56546363 & 58.46696437 \\
\hline $\mathrm{a}-\mathrm{Ca}$ & -567.9370578 & -22.68986865 & 8.941366253 & 90.53505982 \\
\hline $\mathrm{Na}-\mathrm{Al}$ & 92.97134181 & -13.87724934 & -6.691177285 & -176.5269958 \\
\hline$E e-A l$ & 109.0295292 & 47.53201651 & -162.366204 & -442.966157 \\
\hline
\end{tabular}

B.18 


\begin{tabular}{|c|c|c|c|c|}
\hline+ & 2rO2 & Other & Al-AI & \\
\hline $\mathrm{SiO} 2$ & -0.386923928 & -0.340382239 & 7.382393515 & \\
\hline B203 & -7.582691747 & -8.078948004 & & -547.35527 \\
\hline $\mathrm{Na2O}$ & 0.826341235 & -0.002798843 & 5.337240015 & \\
\hline i20 & 1.827387654 & -0.999336243 & 0.371250263 & \\
\hline $\mathrm{CaO}$ & -2.545125592 & 1.010206668 & 32.37635136 & -83.476304 \\
\hline Mgo & 1.195484115 & -0.098465756 & -23.50176981 & \\
\hline $\mathrm{Fe} 203$ & 2.464264187 & 0.671700287 & -69.01515806 & \\
\hline A1203 & 9.420657356 & -0.371088445 & 8.7669945 & \\
\hline $\mathrm{Z}=02$ & 8.207245864 & 1.283148175 & -28.82631721 & 31 . \\
\hline Other & 48175 & 318748 & 9.631219823 & \\
\hline $1-A I$ & 82631721 & 19823 & 85.24609 & -65 \\
\hline $3-B$ & 1.4772274 & 46863 & $6: 4018921$ & 23 \\
\hline$g-A]$ & -16.05478862 & 192103 & 7.6013841 & -32 \\
\hline $\mathrm{B}-\mathrm{Ca}$ & 2.671814798 & 746211 & 04882772 & 36 \\
\hline $\mathrm{Na}-\mathrm{Ca}$ & 1933426 & -10.17954949 & -212.167184 & \\
\hline $\mathrm{Ia}-\mathrm{ALI}$ & -2.923620623 & 3.165569279 & -62.07872502 & $-18 c$ \\
\hline $\mathrm{Fe}-\mathrm{Al}$ & -20.61412192 & 23.40844588 & 1962.791702 & \\
\hline & & & & \\
\hline iO2 & 77074 & & & \\
\hline 203 & 03034 & 86119 & 6496695 & 05868 \\
\hline 20 & 35283 & 390787 & -61.52286717 & 537694 \\
\hline$i 20$ & 14002 & -6.68513554 & 24.10602745 & 740469 \\
\hline $\mathrm{SaO}$ & 71194 & -464.4720217 & -567.9370578 & 134181 \\
\hline go & 942932 & -26.28814366 & -22.68986865 & 7724934 \\
\hline $\mathrm{e} 203$ & 96195 & 546363 & 8.941366253 & 177285 \\
\hline 1203 & 91505 & 96437 & 3505982 & 269958 \\
\hline $\mathrm{ZrO} 2$ & .05478862 & 14798 & 21933426 & 3620623 \\
\hline 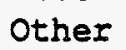 & 92103 & 746211 & 7954949 & 569279 \\
\hline $1-\mathrm{A} 1$ & 013841. & 882772 & 2.167184 & 872502 \\
\hline $3-B$ & $75289^{\circ}$ & 969579 & 376.6153296 & .8999145 \\
\hline $\lg -\mathrm{Al}$ & 90991 & 56547 & 7.025043 & 136091 \\
\hline $\mathrm{B}-\mathrm{Ca}$ & 66547 & 14678 & 7.959568 & 891048 \\
\hline $\mathrm{Na}-\mathrm{Ca}$ & 25043 & 59568 & 3.202545 & .5233654 \\
\hline $\mathrm{Na}-\mathrm{AI}$ & 36091 & -426.3891048 & 0.5233654 & 4.347898 \\
\hline Ee-Al & .8587514 & -303.9119381 & -412.8024043 & -177.748699 \\
\hline
\end{tabular}

B. 19 
$+\quad$ Fe-Al

\begin{tabular}{lr}
$\mathrm{SiO} 2$ & 0.459332966 \\
$\mathrm{~B} 2 \mathrm{O} 3$ & 126.4568466 \\
$\mathrm{Na} 20$ & 16.91902114 \\
$\mathrm{Li} 2 \mathrm{O}$ & 29.52946111 \\
$\mathrm{CaO}$ & 109.0295292 \\
$\mathrm{MgO}$ & 47.53201651 \\
$\mathrm{Ee} 2 \mathrm{O} 3$ & -162.366204 \\
$\mathrm{Al} 203$ & -442.9661573 \\
ZrO2 & -20.61412192 \\
Other & 23.40844588 \\
$\mathrm{Al-A}$ & 1962.791702 \\
$\mathrm{~B}-\mathrm{B}$ & -473.4303576 \\
$\mathrm{Mg}-\mathrm{Al}$ & -735.8587514 \\
$\mathrm{~B}-\mathrm{Ca}$ & -303.9119381 \\
$\mathrm{Na}-\mathrm{Ca}$ & -412.8024043 \\
$\mathrm{Na}-\mathrm{Al}$ & -177.7486993 \\
$\mathrm{Ee}-\mathrm{Al}$ & 5594.623434 \\
\multicolumn{1}{c}{$;$} &
\end{tabular}


TABLE X XXIDPNHL (EXTDHLI, EXTDHLJ) (PCT-sodium) for nonlinear model \#

(XtX) - 1 matrix for durability $\begin{array}{llll}\mathrm{SiO} 2 \mathrm{~B} 2 \mathrm{O} & \mathrm{Na} 2 \mathrm{O} & \mathrm{Li} 2 \mathrm{O}\end{array}$

\begin{tabular}{|c|c|c|c|c|}
\hline $\mathrm{SiO2}$ & 2.300899608 & -8.320367668 & -3.237253572 & -9.22835986 \\
\hline B203 & -8.320367668 & 128.3516866 & 2.871004659 & 11.014484 \\
\hline 20 & 3.237253572 & 2.871004659 & 5.77137561 & 36.5 \\
\hline 20 & 28359863 & 11.0144846 & 36.54907788 & 125 \\
\hline 20 & 2.463821344 & 177863 & -4.130510374 & -6 \\
\hline Mgo & 15.87314561 & 31.69100572 & -12 & 0.918 \\
\hline e203 & -1.018396043 & -8.639163391 & 62 & -3.994 \\
\hline 203 & 1.003858853 & -29.6958 & 761 & -14. \\
\hline 502 & 0.773375912 & -8.26585 & -1.93 & -6.53 \\
\hline her & -0.999675 & -10.26379359 & -0.17 & -0.9896 \\
\hline$i-M g$ & -37.56554932 & -54.10917021 & 28.88 & 43.7 \\
\hline - $\mathrm{Ca}$ & 19.37414525 & -114.8943028 & 20.45 & 29.7 \\
\hline$a-I i$ & 57.33726105 & -1.36 .7580269 & -301.9254992 & -866.493756 \\
\hline$B-B$ & 30.59434199 & -536.9675887 & -16.39 & -59.8244711 \\
\hline$-M g$ & 39.95695379 & -34.36756608 & -60.13272 & -567.805528 \\
\hline -Al & 6.345941937 & 99.08027183 & 10.5393 & 17.65103 \\
\hline & $\mathrm{CaO}$ & MgO & Fe203 & \\
\hline $\mathrm{LO} 2$ & -2.463821344 & & & \\
\hline 203 & 11.5297 & 31.69 & -8.6 & -29 \\
\hline $\mathrm{Na} 2 \mathrm{O}$ & -4.130510374 & -12.5512 & -0.43 & -5.45 \\
\hline 20 & -6.62718 & 0.91894 & -3.994 & -14.50 \\
\hline 10 & 47.256 & -20.145 & -1.304 & 3.9 \\
\hline go & -20.14592008 & 900.859 & -38.27215918 & -56.0 \\
\hline & -1.304034205 & -38.27215 & 811 & 6.77 \\
\hline & & & & \\
\hline & & & & \\
\hline ser & 0.97365606 & -27.608 & 2.353587 & 4.843394 \\
\hline Si-Mg & 55.98950908 & -1711.0 & 67.94 & 115.932394 \\
\hline $\mathrm{B}-\mathrm{Ca}$ & -336.518108 & 173.44 & 7.908981 & -33.1373639 \\
\hline & 94.3 & -3.47059 & & 138.5966 \\
\hline$B-B$ & -13.04847342 & -211.643 & 40.99 & 137.263365 \\
\hline & -63.47512186 & -1150.217801 & 106.7718118 & -31.8200069 \\
\hline & -22.47472216 & 120.7127918 & -12.81802199 & -229.702453 \\
\hline
\end{tabular}




\begin{tabular}{|c|c|c|c|c|}
\hline+ & $\mathrm{ZrO} 2$ & Other & $S i-M g$ & $B-C a$ \\
\hline SiO2 & -0.773375912 & -0.999675 & -37.56554932 & 19.37414525 \\
\hline B203 & -8.265858827 & -10.26379359 & -54.10917021 & -114.8943028 \\
\hline $\mathrm{Na2O}$ & -1.939102947 & -0.177584323 & 28.88362792 & 20.45017697 \\
\hline Li20 & -6.539934833 & -0.989 & 43.77451174 & \\
\hline $\mathrm{CaO}$ & 1.723566833 & 0.97365606 & 55.98950908 & -336.518108 \\
\hline Mgo & -34.61381962 & -27.60878005 & -1711.011537 & 173.4460369 \\
\hline Fe203 & 3.379353536 & 2.353587624 & 67.94912083 & 7.908981959 \\
\hline Al203 & 9.544738848 & 4.843394596 & 115.9323948 & -33.1 \\
\hline ZrO2 & 9.648457552 & 2.725212 & 68.80220078 & -12.61 \\
\hline ther & 2.725212648 & 10.96 & 81 & -0 \\
\hline$i-M g$ & 68.80220078 & 60.0 & .7 .414 & $-4 c$ \\
\hline $\mathrm{B}-\mathrm{Ca}$ & -12.61858325 & -0.60444 & -406.1264 & 998 \\
\hline $\operatorname{Ja}-L_{i}$ & 45.7967486 & $16.5487 \varepsilon$ & -80.0948 & -40 \\
\hline $3-B$ & 38.92546431 & .46 .13 & 3.491 & \\
\hline$i-M g$ & 31.42419857 & -43.85 & 87 & 27 \\
\hline$I-A I$ & -25.02987298 & -7.77 & -28 & \\
\hline & $\mathrm{Na}-\mathrm{Li}$ & $B-B$ & & \\
\hline i02 & 7.33726105 & 99 & & \\
\hline 3203 & -136.7580269 & -536.9 & -34 & \\
\hline 220 & . 9254992 & -16. & -60 & \\
\hline 淐 & -866.4937568 & -59.82 & 1.8055 & 3761 \\
\hline :ao & 94.3284153 & -13.04 & -63.47512 & -22 \\
\hline Mgo & -3.470596052 & -211.6435305 & -1150.217 & 12 \\
\hline $\mathrm{Fe} 203$ & & & 106.7718118 & -12 \\
\hline Al203 & 138.5966045 & 137.2 & -31.82000693 & -22 \\
\hline Zro2 & 45.7967486 & 38.92546431 & 31.42419857 & -25.0 \\
\hline Other & 16.54878252 & 46.13944796 & -43.85033109 & -7.7 \\
\hline$S i-M g$ & -80.09480365 & 383.4914076 & 780.1633987 & -283.2072499 \\
\hline $\mathrm{B}-\mathrm{Ca}$ & -400.2546523 & 157.6107608 & 272.5683837 & 201.5992466 \\
\hline $\mathrm{Na}-\mathrm{Ii}$ & 7673.815773 & 761.0267858 & 1566.598903 & -342.7756346 \\
\hline$B-B$ & 761.0267858 & 2344.158012 & 208.909845 & -478.7471422 \\
\hline $\mathrm{Li}-\mathrm{Mg}$ & 1566.598903 & 208.909845 & 18180.16327 & 557.6640032 \\
\hline$A 1-A l$ & -342.7756346 & -478.7471422 & 557.6640032 & 1290.924507 \\
\hline
\end{tabular}


TABLE XtXITLCIHL (EXTDHLI, EXTDHLJ). (XtX)-1 matrix for TL-Cl model

$$
\text { SiO2 } \quad \text { B2O3 Na2O Li2O }
$$

\begin{tabular}{|c|c|c|c|c|}
\hline $\begin{array}{l}\mathrm{SiO2} \\
\mathrm{B} 2 \mathrm{O} 3\end{array}$ & $\begin{array}{l}15.33624116 \\
2.721480014\end{array}$ & $\begin{array}{l}2.721480014 \\
50.73296717\end{array}$ & $\begin{array}{r}-7.731138814 \\
2.866733075\end{array}$ & $\begin{array}{l}-45.88503111 \\
-6.966217531\end{array}$ \\
\hline $\mathrm{Na} 2 \mathrm{O}$ & -7.731138814 & 2.866733075 & 34.05702884 & 31.07079651 \\
\hline Li20 & -45.88503111 & -6.966217531 & 31.07079651 & 329.1377321 \\
\hline $\mathrm{CaO}$ & -11.57191558 & 7.301316248 & 12.77805795 & 2.600051286 \\
\hline Mgo & -7.632414919 & 41.11895403 & 1.185289875 & -2.932355674 \\
\hline Fe203 & -22.45150452 & -32.99153855 & -21.49480829 & 30.20928784 \\
\hline A 203 & -23.5420828 & -62.55639216 & -13.52783767 & 17.1738127 \\
\hline zro2 & -34.68281851 & -47.15879835 & -6.867038133 & 155.7116344 \\
\hline Other & -23.31257092 & -22.24694916 & 10.24142926 & -24.13308896 \\
\hline+ & $\mathrm{CaO}$ & Mgo & $\mathrm{Fe} 203$ & Al203 \\
\hline $\mathrm{SiO} 2$ & -11.57191558 & -7.632414919 & -22.45150452 & -23.5420828 \\
\hline B2O3 & 7.301316248 & 41.11895403 & -32.99153855 & -62.55639216 \\
\hline $\mathrm{Na2O}$ & 12.77805795 & 1.185289875 & -21.49480829 & -13.5278376 \\
\hline Li20 & 2.600051286 & -2.932355674 & 30.20928784 & 17.1738127 \\
\hline $\mathrm{CaO}$ & 134.6993369 & 28.47029814 & -16.32258516 & -31.9032708 \\
\hline Mgo & 28.47029814 & 254.933063 & -10.80295375 & -95.3917620 \\
\hline $\mathrm{Ee} 203$ & -16.32258516 & -10.80295375 & 115.2773998 & 109.3283 \\
\hline Al203 & -31.90327088 & -95.39176201 & 109.32833 & 190.361596 \\
\hline $\mathrm{ZrO} 2$ & -13.79025218 & -86.42449712 & 75.48137845 & 115.686862 \\
\hline Other & 51.1794025 & 36.05684615 & 33.15492967 & 43.2023688 \\
\hline & ZrO2 & Other & & \\
\hline
\end{tabular}

$\begin{array}{lrr}\mathrm{SiO} 2 & -34.68281851 & -23.31257092 \\ \mathrm{~B} 2 \mathrm{O} 3 & -47.15879835 & -22.24694916 \\ \mathrm{Na2O} & -6.867038133 & 10.24142926 \\ \mathrm{Li2O} & 155.7116344 & -24.13308896 \\ \mathrm{CaO} & -13.79025218 & 51.1794025 \\ \mathrm{MgO} & -86.42449712 & 36.05684615 \\ \mathrm{Fe} 203 & 75.48137845 & 33.15492967 \\ \mathrm{Al2O3} & 115.6868622 & 43.20236887 \\ \text { ZrO2 } & 270.4216398 & 9.809937389 \\ \text { Other } & 9.809937389 & 157.1526726\end{array}$


TABLE XtXITLSpHL (EXTDHLI, EXTDHLJ) (XtX)-1 matrix for TL-Sp model

$\begin{array}{llll}\mathrm{SiO} & \mathrm{B2O} & \mathrm{Na} 2 \mathrm{O} & \mathrm{Li} 2 \mathrm{O}\end{array}$

\begin{tabular}{|c|c|c|c|c|}
\hline $\mathrm{SiO} 2$ & 12.27477942 & -7.244986532 & -5.775434397 & -25.03994891 \\
\hline B203 & -7.244986532 & 39.16857817 & 2.322680502 & 59.51403069 \\
\hline Na2O & -5.775434397 & 2.322680502 & 51.20981716 & 20.67566279 \\
\hline Li20 & -25.03994891 & 59.51403069 & 20.67566279 & 297.2932401 \\
\hline $\mathrm{CaO}$ & -1.203685605 & 36.71532139 & -10.79003812 & 145.9593821 \\
\hline Mgo & -11.81130782 & 5.523252651 & -3.520013128 & -38.85376167 \\
\hline $\mathrm{Fe} 203$ & -20.92691484 & -4.343722557 & -12.44577308 & -19.18007319 \\
\hline Al203 & -12.61849615 & -45.5004805 & 0.934552666 & -92.13203042 \\
\hline $\mathrm{Z} 502$ & -21.18567511 & -16.46195008 & -4.134106374 & 11.1127 .1276 \\
\hline Other & -14.21064028 & -18.24789444 & -32.30456106 & -84.04316537 \\
\hline+ & $\mathrm{CaO}$ & MgO & $\mathrm{Fe} 203$ & Al203 \\
\hline SiO2 & -1.203685605 & -11.81130782 & -20.92691484 & -12.61849615 \\
\hline B2O3 & 36.71532139 & 5.523252651 & -4.343722557 & -45.5004805 \\
\hline $\mathrm{Na} 2 \mathrm{O}$ & -10.79003812 & -3.520013128 & -12.44577308 & 0.934552666 \\
\hline Li20 & 145.9593821 & -38.85376167 & -19.18007319 & -92.132030 .42 \\
\hline $\mathrm{CaO}$ & 156.2214885 & -17.06746615 & -32.63419591 & -89.11921951 \\
\hline MgO & -17.06746615 & 122.9555369 & 38.69668551 & 25.89201033 \\
\hline $\mathrm{Fe} 203$ & -32.63419591 & 38.69668551 & 76.29678186 & 58.3693502 \\
\hline Al203 & -89.11921951 & 25.89201033 & 58.3693502 & 135.8339794 \\
\hline Zro2 & -14.8205397 & -9.816356271 & 39.32146123 & 61.968641 \\
\hline Other & -71.18238546 & 26.73836216 & 60.80501747 & 62.86905225 \\
\hline+ & $\mathrm{ZrO2}$ & Other & & \\
\hline SiO2 & -21.18567511 & -14.21064028 & & \\
\hline B2O3 & -16.46195008 & -18.24789444 & & \\
\hline $\mathrm{Na} 2 \mathrm{O}$ & -4.134106374 & -32.30456106 & & \\
\hline Li20 & 11.11271276 & -84.04316537 & & \\
\hline $\mathrm{CaO}$ & -14.8205397 & -71.18238546 & & \\
\hline MgO & -9.816356271 & 26.73836216 & & \\
\hline $\mathrm{Fe} 203$ & 39.32146123 & 60.80501747 & & \\
\hline Al2O3 & 61.968641 & 62.86905225 & & \\
\hline $\mathrm{ZrO}$ & 153.2981429 & 54.48047616 & & \\
\hline Other & 54.48047616 & 137.1994924 & & \\
\hline
\end{tabular}


TABLE XtXITLSPHL (EXTDHLI, EXTDHLJ) (XtX)-1 matrix for TL-Sp model

$\begin{array}{llll}\mathrm{SiO} 2 & \mathrm{~B} 2 \mathrm{O} & \mathrm{Na} 2 \mathrm{O} & \text { Li2O }\end{array}$

\begin{tabular}{|c|c|c|c|c|}
\hline SiO2 & 12.27477942 & -7.244986532 & -5.775434397 & -25.03994891 \\
\hline B203 & -7.244986532 & 39.16857817 & 2.322680502 & 59.51403069 \\
\hline $\mathrm{Na2O}$ & -5.775434397 & 2.322680502 & 51.20981716 & 20.67566279 \\
\hline Ii20 & -25.03994891 & 59.51403069 & 20.67566279 & 297.2932401 \\
\hline $\mathrm{CaO}$ & -1.203685605 & 36.71532139 & -10.79003812 & 145.9593821 \\
\hline MgO & -11.81130782 & 5.523252651 & -3.520013128 & -38.85376167 \\
\hline $\mathrm{Fe} 203$ & -20.92691484 & -4.343722557 & -12.44577308 & -19.18007319 \\
\hline A 203 & -12.61849615 & -45.5004805 & 0.934552666 & -92.13203042 \\
\hline $\mathrm{ZrO} 2$ & -21.18567511 & -16.46195008 & -4.134106374 & 11.11271276 \\
\hline Other & -14.21064028 & -18.24789444 & -32.30456106 & -84.04316537 \\
\hline+ & $\mathrm{CaO}$ & Mgo & $\mathrm{Fe} 203$ & Al203 \\
\hline $\mathrm{SiO} 2$ & -1.203685605 & -11.81130782 & -20.92691484 & -12.61849615 \\
\hline B203 & 36.71532139 & 5.523252651 & -4.343722557 & -45.5004805 \\
\hline $\mathrm{Na} 20$ & -10.79003812 & -3.520013128 & -12.44577308 & 0.934552666 \\
\hline Li20 & 145.9593821 & -38.85376167 & -19.18007319 & -92.13203042 \\
\hline $\mathrm{CaO}$ & 156.2214885 & -17.06746615 & -32.63419591 & -89.11921951 \\
\hline MgO & -17.06746615 & 122.9555369 & 38.69668551 & 25.89201033 \\
\hline Fe203 & -32.63419591 & 38.69668551 & 76.29678186 & 58.3693502 \\
\hline Al203 & -89.11921951 & 25.89201033 & 58.3693502 & 135.8339794 \\
\hline ZrO2 & -14.8205397 & -9.816356271 & 39.32146123 & 61.968641 \\
\hline Other & -71.18238546 & 26.73836216 & 60.80501747 & 62.86905225 \\
\hline+ & 2rO2 & Other & & \\
\hline & & - 7 0909000 & & \\
\hline$B 203$ & -16.46195008 & -18.24789444 & & \\
\hline $\mathrm{Na} 2 \mathrm{O}$ & -4.134106374 & -32.30456106 & & \\
\hline $\operatorname{Li20}$ & 11.11271276 & -84.04316537 & & \\
\hline $\mathrm{CaO}$ & -14.8205397 & -71.18238546 & & \\
\hline MgO & -9.816356271 & 26.73836216 & & \\
\hline $\mathrm{Fe} 203$ & 39.32146123 & 60.80501747 & & \\
\hline Al203 & 61.968641 & 62.86905225 & & \\
\hline $\mathrm{ZrO} 2$ & 153.2981429 & 54.48047616 & & \\
\hline Other & 54.48047616 & 137.1994924 & & \\
\hline
\end{tabular}




\title{
APPENDIX C
}

\author{
Blending Behavior \\ Summary from FY94 Blend Report
}




\section{Appendix C \\ Blending Behavior Summary from \\ FY94 Blend Report}

This appendix summarizes the accumulated understanding of blending, its role, its behavior. It originally appeared in the FY94 Blend report.

\section{Blending Behavior}

\section{Effect of Constraints}

- Blending is most beneficial when the system is tightly constrained by single component or multi-component crystallinity constraints.

- Blending offers little reduction in the number of glass logs when all constraints except glass property constraints are removed.

- Blending wastes with the same binding constraint does not reduce the number of glass logs.

\section{Effect of Blend Size}

- The benefit gained from blending increases with the number of wastes in each blend (i.e., for a given waste set, the Total Blend is always best. It is often possible to match Total Blend performance with a small number of optimally formulated blends).

\section{Bounds on Blending Benefit}

- For discrete blending of a waste set, the best blend may be as good as but not better than the Total Blend; the worst blend may be as bad as but not worse than the No Blend case. There may be a wide range of performance among the different blending combinations.

a The word "not" was inadvertently omitted from this sentence in the FY94 Blend report. 
- Continuous blending of a waste set will equal the performance of the Total Blend

\section{Criteria for Evaluating Blending Strategies}

- Blending strategies can be compared by comparing the total number of glass logs produced by vitrification of a set of tank wastes.

- Blending strategies must be evaluated in the context of the entire waste set:

- Can form good blends but leave bad balance of wastes (waste complement)

- Müst consider effect of blend selection on total waste set

- Determine total number of logs for waste set and its complement.

- Comparisons are only valid if the same glass constraints are used for all blending strategies compared

\section{Blend Formulation Strategies}

\section{What to Blend When}

- To gain maximum reduction in glass logs required, blend wastes of very different compositions.

- Any blending of wastes done prior to pretreatment ("early") should be of similar wastes to avoid dilution of species to be removed.

- Blend similar wastes prior to pretreatment and dissimilar wastes ( pretreated early blends)' after pretreatment.

\section{Techniques for Formulating Blends}

- Based on preliminary results obtained so far, simulated annealing appears to be a very effective mathematical method for formulating blends.

- Experience so far with solving the discrete blending problem with MINLP/DICOPT has been good with very small waste sets. Further experience with the method should enable us to get better results with larger waste sets.

- Random blending MAY work satisfactorily with large sets of tanks and large blend sizes, assuming numerous optimal or near-optimal solutions.

- Blending by retrieval annex and tank farm is recommended only for early blending.

- Alternate formulations of the blending optimization problem may prove useful in formulating blends. 
- Formulating blends by distributing masses of limiting components evenly among the blends is a simple strategy that can be performed manually.

- Optimal blends OptiBlends can be produced if the binding constraint for each of the blends is the same as for the Total Blend. This may not be possible for small tank sets and blend sizes; but may be very achievable for larger tank sets and blend sizes.

\section{Approaches for Increasing Waste Loading and Reducing Volume of Glass Produced}

There are several approaches one can take to increase the waste loading in the giass and reduce the volume of glass produced.

- Relax Constraints - In the OWL calculations, the waste loading is increased until a constraint prevents it from being increased further. If one or more constraints are relaxed or removed, the waste loading can be increased further. Experimental studies may be able to show that some of the more restrictive constraints can be relaxed or removed.

- Pretreat to Remove Troublesome Species and Reduce Mass of Waste to Be Vitrified - For those components whose constraints cannot be relaxed or removed, pretreatment methods may be able to substantially reduce their concentration in the waste such that these components are no longer limiting.

- Blend to Average out Troublesome Species - Blending can very effectively decrease the amount of vitrified waste glass produced though the extent of the benefit from blending diminishes as constraints are relaxed and troublesome components removed (i.e., by pretreatment).

- Combination of Above - All three methods above can provide a benefit. All three should be used in combination to provide the maximum benefit.

\section{Caveats}

- Calculated numerical results depend on waste compositions, constraints, and assumed pretreatments - all of which are likely to change 
- These resuits were obtained by studying only high-level waste vitrification. Much of the behavior could be applicable to low-level vitrification. The blending behavior of low-level glass can be examined after experimentally derived glass models become available.

- These results do not address tank farm logistics, safety issues, or processing schedules. (Though the strategy described in Section 6 does address these issues)

- All calculations have assumed perfect blending of wastes uniform in composition 
Appendix D

Waste Compositions - Tank Farm Blends 
I

\begin{tabular}{|c|c|c|c|c|}
\hline 000028 โ0:0 & $0009920^{\circ} 0$ & & & soz \\
\hline 0009 IS00 0 & $00069\left[00^{\circ} 0\right.$ & $0000 Z \angle O O 0^{\circ} 0$ & $000 \varepsilon \tau\left[00^{\circ} 0\right.$ & \\
\hline $08 \angle Z 0000^{\circ} 0$ & $0 \angle Z D 0000^{\circ} 0$ & $0006 S T 00^{\circ} 0$ & $00062000^{\circ} 0$ & EOZx? \\
\hline $00086228 \cdot 0$ & 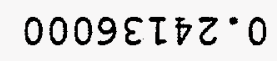 & $00 \angle 299 \angle \varepsilon^{\bullet} 0$ & $00 \nabla \sigma Z \angle \sigma I \cdot 0$ & \\
\hline $0009 \tau 200^{\circ} 0$ & $000 乙 \varepsilon \varepsilon 00^{\circ} 0$ & $000 \angle I Z 00^{\circ} 0$ & 009 IS000 0 & \\
\hline $00000 \varepsilon Z \tau \cdot 0$ & $000000 \varepsilon Z \cdot 0$ & $00000270 \cdot 0$ & 00009 DI0.0 & \\
\hline 00006860.0 & $0000 \tau 650.0$ & $0000 \varepsilon 6 \angle 0^{\circ} 0$ & $00000 \varsigma \varepsilon Z \cdot 0$ & \\
\hline $00000000^{\circ} 0$ & $00000000^{\circ} 0$ & $00000000^{\circ} 0$ & $00000000^{\circ} 0$ & \\
\hline $00009950 \cdot 0$ & $000 Z Z 200^{\circ} 0$ & $00 \varepsilon S 2000^{\circ} 0$ & $00006 \angle 20^{\circ} 0$ & \\
\hline $00000000 \cdot 0$ & $00000000^{\circ} 0$ & $00000000^{\circ} 0$ & $00000000^{\circ} 0$ & \\
\hline $000008 \varepsilon Z \cdot 0$ & 00000 ISZ $^{\circ} 0$ & $00000225 \cdot 0$ & 000006 IS $^{\circ} 0$ & \\
\hline $00000000^{\circ} 0$ & $00000000^{\circ} 0$ & $00000000^{\circ} \cdot 0$ & $00000000 \cdot 0$ & \\
\hline $0000 \nabla 850^{\circ} 0$ & $00000 \nabla \tau Z^{\circ} 0$ & $000 \subseteq 9 \angle 00^{\circ} 0$ & $000 \approx \angle S 00^{\circ} 0$ & \\
\hline$x g$ & $\mathrm{xg}$ & $\varepsilon$ & $X \mathbb{Z}$ & \\
\hline $00066 \varepsilon$ & 00000SOT & $000008 I I$ & 000002 & \\
\hline $00000000^{\circ} 0$ & $00 S E \angle 000^{\circ} 0$ & 00 โZ2000:0 & $000 \varepsilon 0900^{\circ} 0$ & \\
\hline $000 \tau \tau \nabla 00^{\circ} 0$ & OOOโ૪ $800^{\circ} 0$ & $000 \nabla \tau E 00^{\circ} 0$ & $000 \varepsilon \subseteq 900^{\circ} 0$ & \\
\hline $00 \angle \tau Z 000^{\circ} 0$ & 0000 ILBO 0 & $0000 Z \angle D 0^{\circ} 0$ & $00069800^{\circ} 0$ & \\
\hline $000 \varepsilon 0000^{\circ} 0$ & $000 \varsigma s \varsigma 00^{\circ} 0$ & $00085500^{\circ} 0$ & $00 \angle 96000^{\circ} 0$ & \\
\hline $00 \varepsilon \nabla 0000^{\circ} 0$ & $00025700^{\circ} 0$ & $0000 S 700^{\circ} 0$ & 000 T9200.0 & \\
\hline $008 Z \angle 00 Z{ }^{\circ} 0$ & OID $\angle O D I E^{\circ} O$ & OTILODIE $\varepsilon^{\circ} 0$ & $980 B L E I C^{\circ} 0$ & хәч \\
\hline 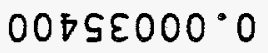 & $.000080<0$ & $000080 \angle 0^{\circ} 0$ & 00000 IST $^{\circ} 0$ & \\
\hline $000080 \tau 0^{\circ} 0$ & $000000 E \tau^{\circ} 0$ & $000000 \varepsilon I \cdot 0$ & $0000 \tau 060^{\circ} 0$ & $\varepsilon O Z$ \\
\hline $00000965^{\circ} 0$ & $000000 \tau I \cdot 0$ & $000000 I I^{\circ} 0$ & $00000 \tau 82^{\circ} 0$ & عOZ \\
\hline 000 & $000^{\circ} 0$ & $0099 \angle 000^{\circ} 0$ & 000 โ0Z00.0 & \\
\hline 008 โE000 0 & $00009020^{\circ} 0$ & $00009020^{\circ} 0$ & $00068 \angle 00^{\circ} 0$ & \\
\hline $00000000^{\circ} 0$ & $06900000^{\circ} 0$ & $06800000^{\circ} 0$ & $\nabla 8 \tau 00000^{\circ} 0$ & \\
\hline $00000 \varepsilon \angle I^{\circ} 0$ & $00000 \varepsilon S Z \cdot 0$ & $00000 \varepsilon s Z^{\circ} 0$ & $000000 โ Z^{\circ} 0$ & \\
\hline $00000000^{\circ} 0$ & $0 O B S \angle 000^{\circ} 0$ & $0 O B S \angle 000^{\circ} 0$ & $0 \varepsilon \angle S 0000^{\circ} 0$ & \\
\hline $00008 \div 20.0$ & $0000000 \tau \cdot 0$ & $0000000 I \div 0$ & $00002000^{\circ} 0$ & \\
\hline$\forall$ & ISQUISS & $T T H$ & MHDN & \\
\hline
\end{tabular}

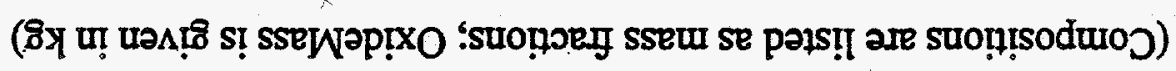

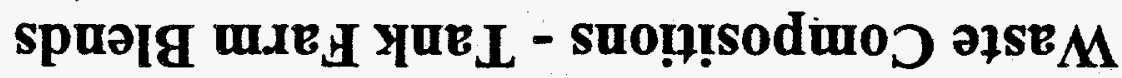 \\ a xipuədd $\forall$}


SO3 $0.00018400 .0 .00180000 \quad 0.00540000 \quad 0.00227000$ NobMet $\quad 0.00000000 \quad 0.00000000 \quad 0.00000000 \quad 0.00000000$

OxideMass

65900

1150000

1160000

1200000

D.2 


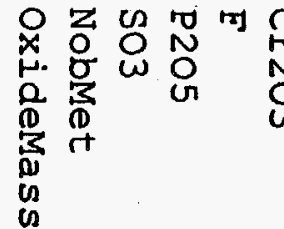

00000 N 숭요요용 응부요용

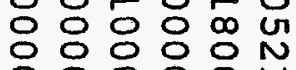
응ㅇㅇㅇㅛ

00000 - 0000 म잉 or 0 光 $\omega \omega$ 0 O $\begin{array}{llllll}0 & 0 & 0 & 0 & 1 & w \\ 0 & 0 & 0 & 0 & 0 & 0\end{array}$ 00000 웅ㅇㅇㅇㅇㅇ 200010 a 0 o 1 ᄀ 10 8.

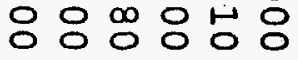

00000

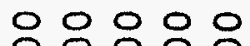
ᄀ 08080 $\triangle O \sim \mapsto \Omega N$ $\triangle O N \infty$ U $\omega$ O O 0 O

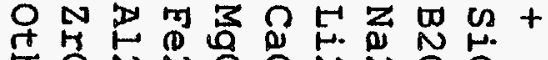

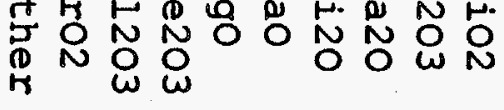

0000000000 w i i i i i i i N 0 ㄴ A $\infty \omega 000 \%$

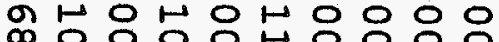

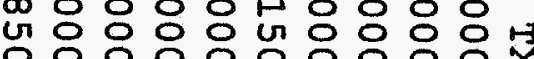

0000000000 NOHiOOOONON ONOUOOO

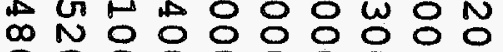
0 O 000 o 0 O 00 응ㅇㅇㅇㅇㅇㅇㅇㅇㅇㅇㅇㅇㅇㅇㅇㅇㅇㅇㅇㅇㅇㅢ

0000000000 Noㅂㅇㅇㅇㅇㅇㅇㅎㅏ N N $00 \%$

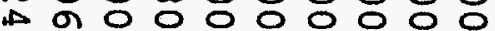

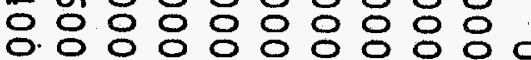

0000000000 - O O O O o o o N

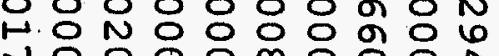
ᄀ «O N $O$ N 0000 i

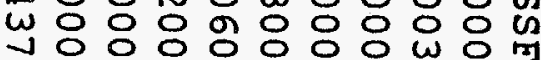

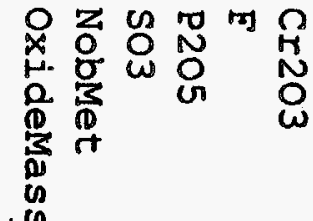
00000 웅 680809 $\infty O H N G$ ○의 응응겅ㅎㅇㅇㅇㅇ 00000 . - 00000

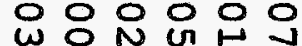
O O 근 OOO

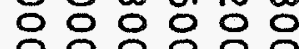

$$
00000
$$

$\circ \circ 0^{\circ} \circ$

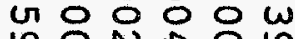
6 O

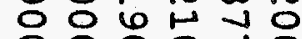
ㅇㅇㅇㅇㅇㅇㅇㅇㅇㅇㅇㅇ

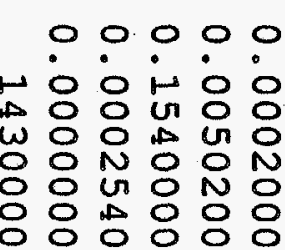

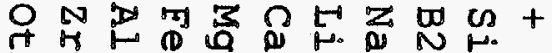

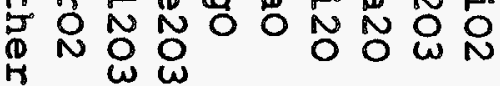
r $\omega$

0000000000 w u

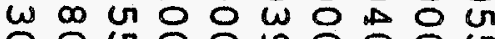

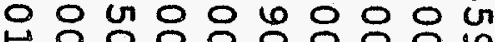

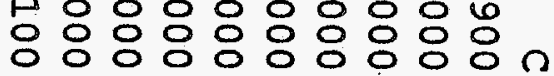

0000000000 足. 은

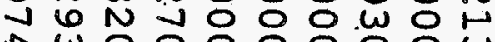
¿

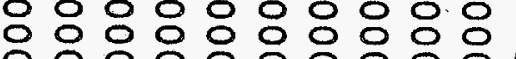

0000000000

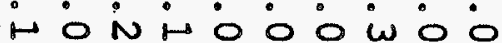

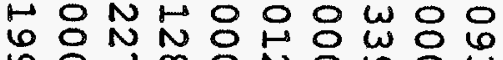
엄 N o

0000000000 Noㅇㅇㅇㅇㅇㅇㅇㅇㅇ

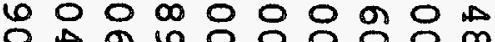
$1 \mathrm{~N}$ un 0 N $\omega$ U 00000

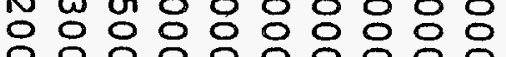


$\therefore \ldots$

$+$

$\mathrm{SiO} 2$

DST

$\mathrm{B} 203$

0.0831000

$\mathrm{Na} 20$

0.0047500

Li20

0.3200000

$\mathrm{CaO}$

0.0000613

$\mathrm{MgO}$

0.0079500

$\mathrm{Fe} 203$

0.0026800

A1203

0.0075000

$\mathrm{ZrO} 2$

0.0265000

other

0.3520000

0.1954587

Cr203 0.0039700

E $\quad 0.0143000$

P205 $\quad 0.0338000$

SO3 $\quad 0.0043400$

NobMet $\quad 0.0006870$

OxideMass 1190000

; 